\title{
Cation- and Anion-Mediated Supramolecular Assembly of Bismuth and Antimony Tris(3-pyridyl) Complexes
}

\author{
Álvaro García-R,omero, Jose M. Martín-Álvarez, Daniel Miguel, Dominic S. Wright, \\ Celedonio M. Álvarez,* and Raúl García-Rodríguez*
}

Cite This: https://doi.org/10.1021/acs.inorgchem.1c03004

Read Online

ACCESS |

山ll Metrics \& More

回 Article Recommendations

Supporting Information

ABSTRACT: The use of antimony and bismuth in supramolecular chemistry has been largely overlooked in comparison to the lighter elements of Group 15, and the coordination chemistry of the tripodal ligands $\left[\mathrm{Sb}(3-\mathrm{py})_{3}\right]$ and $\left[\mathrm{Bi}(3-\mathrm{py})_{3}\right]$ (L) containing the heaviest p-block element bridgehead atoms has been unexplored. We show that these ligands form a common hybrid metal-organic framework (MOF) structure with $\mathrm{Cu}(\mathrm{I})$ and $\mathrm{Ag}(\mathrm{I})$ (M) salts of weakly coordinating anions $\left(\mathrm{PF}_{6}^{-}, \mathrm{SbF}_{6}{ }^{-}\right.$, and $\left.\mathrm{OTf}^{-}\right)$, composed of a cationic substructure of rhombic cage $(\mathrm{M})_{4}(\mathrm{~L})_{4}$ units linked by $\mathrm{Sb} / \mathrm{Bi}-\mathrm{M}$ bonding. The greater Lewis acidity of $\mathrm{Bi}$ compared to $\mathrm{Sb}$ can, however, allows anion $\cdots \mathrm{Bi}$ interactions to overcome $\mathrm{Bi}-$ metal bonding in the case of $\mathrm{BF}_{4}^{-}$, leading to collapse of the MOF structure (which is also seen where harder metals like $\mathrm{Li}^{+}$are employed). This study therefore provides insight into the way in which the electronic effects of the bridgehead atom in these ligand systems can impact their supramolecular chemistry.

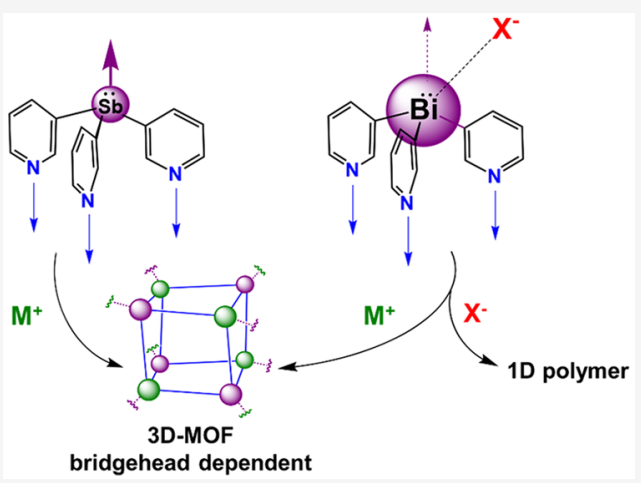

\section{INTRODUCTION}

Tripodal and facially coordinating ligands have far-reaching applications in modern coordination, organometallic, and bioinorganic chemistry. ${ }^{1-7}$ Tris(pyrazolyl) borates are ideal ligands in this area (Figure 1a), mostly because their electronic and steric characteristics can be easily changed by introducing different substituents within the pyrazolyl ring units, thereby tuning the ligand environment to the particular requirements of the coordinated metal atom. ${ }^{8}$ Recently, there has been a resurgence of interest in closely related tris(2-pyridyl) ligands. In the last 4 decades, studies have focused on tris(2-pyridyl) ligands containing nonmetallic bridgehead atoms, $\mathrm{E}(2-\mathrm{py})_{3}(\mathrm{E}$ $=\mathrm{CR}, \mathrm{COR}, \mathrm{CH}, \mathrm{N}, \mathrm{P}, \mathrm{P}=\mathrm{O}$, etc.; 2-py = 2-pyridyl; Figure 1b). ${ }^{9}$ However, incorporating heavier and more metallic maingroup bridgehead atoms has been shown to provide an important tool for tuning the ligand character, enabling systematic modification of the bite angle, donor/acceptor properties, and reactivity. ${ }^{10-21} \mathrm{~A}$ case in point is the series of Group 15 tris(2-pyridyl) ligands E(6-Me-2-py) ${ }_{3}$ (6-Me-2-py = 6-methyl-2-pyridyl; $\mathrm{E}=\mathrm{As}, \mathrm{Sb}, \mathrm{Bi})$ for which changing the bridgehead can be used to provide incremental change in the $\sigma$-donor character and (thereby) the catalytic activity and behavior. $^{22}$

Most recently, attention has been directed to the effects of moving the donor $\mathrm{N}$ atoms from the 2 position to the 3 and 4 positions of the pyridyl ring units. ${ }^{23-25}$ The expected result is that the ligand character switches from the intramolecular N,N,N-chelation mode normally observed for the tris $(2$ - pyridyl) ligands (Figure 1c) to the separate use of the donor $\mathrm{N}$ atoms in intermolecular bonding (Figure 1d,e). This modification can therefore be employed as a strategy for the formation of cages and metal-organic frameworks (MOFs). Indeed, the limited studies of the phosphorus ligand $\mathrm{P}(3-\mathrm{py})_{3}$ have already indicated how the different coordination vectors of tris(3-pyridyl) ligands can be used in supramolecular chemistry.

So far, structural studies of the coordination chemistry of tris(3-pyridyl) ligands containing the heavier main-group elements have been limited to the very recently prepared $\mathrm{Li}\left[\mathrm{EtAl}(3-\mathrm{py})_{3}\right]$ (whose coordination chemistry was not explored $)^{30}$ and those of Group 14. In accordance with expectations, the $\mathrm{MeSi}(3-\mathrm{py})_{3}{ }^{31-33}$ and (air-stable) $\mathrm{PhSn}(3-$ py) ${ }_{3}{ }^{34}$ ligands have been shown to form cage and $1 \mathrm{D}$ or $2 \mathrm{D}$ network arrangements with metal ions. Particularly relevant to the current study is the cage $\left[\left\{\mathrm{PhSn}(3-\mathrm{py})_{3}\right\}_{4}(\mathrm{Cu}\right.$. $\left.\mathrm{MeCN})_{4}\left(\subset \mathrm{PF}_{6}\right)\right]^{3+}$, formed by the coordination of $\mathrm{CuPF}_{6}$ by $\mathrm{PhSn}(3-\mathrm{py})_{3}$ in acetonitrile $(\mathrm{MeCN})$ because of the templating effect of $\mathrm{PF}_{6}{ }^{-34}$ The cage consists of a roughly cubic $\mathrm{Sn}_{4} \mathrm{Cu}_{4}$ arrangement in which the $\mathrm{Sn}$ and $\mathrm{Cu}$ atoms form the corners,

Received: September 25, 2021 
a)<smiles>[H][R5](n1cccn1)n1cccn1</smiles>

b)<smiles>c1ccc(C2c3cccnc3Cc3cccnc32)nc1</smiles>

$E=N, P, C R, C O R, S n R, S^{\prime}$ c)

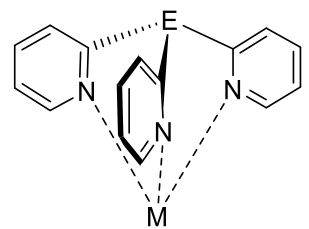

d)

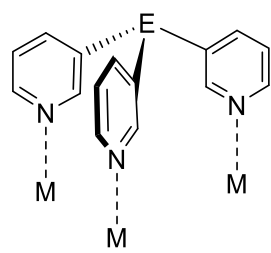

e)<smiles></smiles>

Figure 1. (a) Tris(pyrazolyl) borate ligand framework, (b) nonmetallic "classical" tris(2-pyridyl) ligands, (c) typical N,N,N-coordination mode of $\mathrm{E}(2-\mathrm{py})_{3}$ ligands, (d) switch to an intermolecular coordination vector for $\mathrm{E}(3-\mathrm{py})_{3}$ ligands, and (e) switching of the coordination vector for $\mathrm{E}$ (4py) $)_{3}$ ligands.

with a $\mathrm{PF}_{6}{ }^{-}$anion being encapsulated in the molecular void (Figure 2).

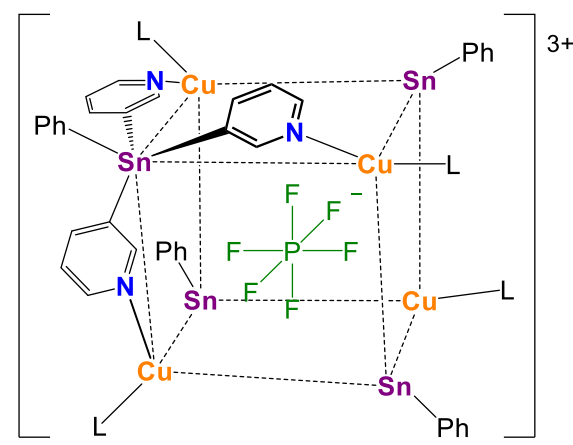

Figure 2. Discrete $\left[\left\{\mathrm{PhSn}(3-\mathrm{py})_{3}\right\}_{4}(\mathrm{Cu} \cdot \mathrm{MeCN})_{4}\left(\subset \mathrm{PF}_{6}\right)\right]^{3+}$ cation found in the structure of the $\mathrm{CuPF}_{6}$ complex of $\mathrm{PhSn}(3-\mathrm{py})_{3}(\mathrm{~L}=$ $\mathrm{MeCN}$ ).

In the current study, we explore the coordination chemistry of the Group 15 ligands $\mathrm{E}(3-\mathrm{py})_{3}[\mathrm{E}=\mathrm{Sb}(1), \mathrm{Bi}(2)]$ for the first time, with monovalent metal cations $\left(\mathrm{M}=\mathrm{Cu}^{+}, \mathrm{Ag}^{+}\right.$, and $\mathrm{Li}^{+}$). Ligands 1 and $\mathbf{2}$ are observed to adopt either a tridentate $\mathrm{N}, \mathrm{N}, \mathrm{N}$-bonding mode or a tetradentate $\mathrm{N}, \mathrm{N}, \mathrm{N}, \mathrm{E}$-bonding mode. Strikingly, however, using the N,N,N,E-bonding mode, we are able to combine the ability to form molecular cages with the ability to construct MOF arrangements, resulting in a series of isostructural hybrid MOFs composed of $\mathrm{E}_{4} \mathrm{M}_{4}$ cage units linked by $\mathrm{E}-\mathrm{M}$ bonding. Unusually, this structure direction appears to be almost completely independent of the anions present, with the same 3D MOF arrangement being formed regardless of the chemical nature and size of the anion. This situation differs from the anion direction commonly found in supramolecular chemistry ${ }^{35,36}$ as well as that seen previously in Group 14 tris(3-pyridyl) metal complexes, in which the chemical and physical characters of the anion normally have profound effects on supramolecular assembly. ${ }^{34}$

\section{RESULTS AND DISCUSSION}

Ligand Synthesis. The first step in our studies was to develop efficient syntheses of the key ligands 1 and 2. The most obvious route that has been applied to various tris(2pyridyl) ligands previously, involving reaction of the element trihalides $\mathrm{EX}_{3}(\mathrm{E}=\mathrm{Sb}, \mathrm{Bi} ; \mathrm{X}=\mathrm{Cl}, \mathrm{Br})$ with 3-lithiopyridine, failed to produce 1 and 2 , leading to a complex mixture of unidentified products. However, we found that both ligands can be obtained easily via the one-pot reactions of 3bromopyridine with the turbo-Grignard $\mathrm{iPrMgCl} \cdot \mathrm{LiCl}^{37}$ at 0 ${ }^{\circ} \mathrm{C}$ in tetrahydrofuran (THF), followed by the addition of $\mathrm{EBr}_{3}$ $(\mathrm{E}=\mathrm{Sb}, \mathrm{Bi})$, with 1 and 2 being isolated in 74 and $80 \%$ crystalline yields, respectively (Scheme 1 and the Experimental Section). The reaction time, solvent, and metal halide used were found to be vital to obtaining high yields of 1 and 2. In particular, the use of $\mathrm{ECl}_{3}$ instead of $\mathrm{EBr}_{3}$ led to a large reduction in their yields. Previously, the Bi ligand 2 had been prepared using the reaction of $\mathrm{BiCl}_{3}$ with the zinc reagent 3$(\mathrm{ZnBr})$-pyridine in low yield $(20 \%) .{ }^{38}$ However, this low yield has limited its utility, and therefore no structural studies of its coordination compounds had appeared prior to the current study.

Compounds $\mathbf{1}$ and $\mathbf{2}$ are thermally stable and can be stored indefinitely in solid form under a $\mathrm{N}_{2}$ atmosphere. They are also remarkably stable toward moisture. No hydrolysis was observed for 1 week after the addition of either ca. 10 equiv of $\mathrm{H}_{2} \mathrm{O}$ in $\mathrm{CDCl}_{3}$ or deuterated dimethyl sulfoxide (DMSO-

Scheme 1. Synthesis of the Heavier Group 15 Ligands 1 and 2

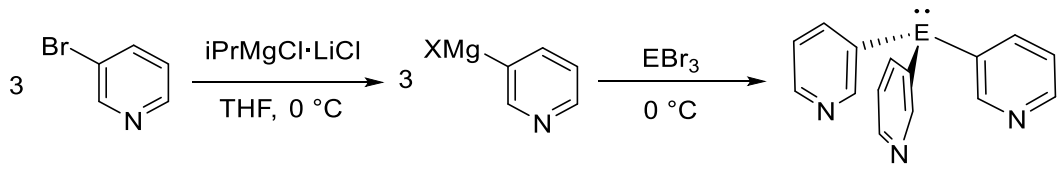$$
E=S b(1), B i(2)
$$ 
a)
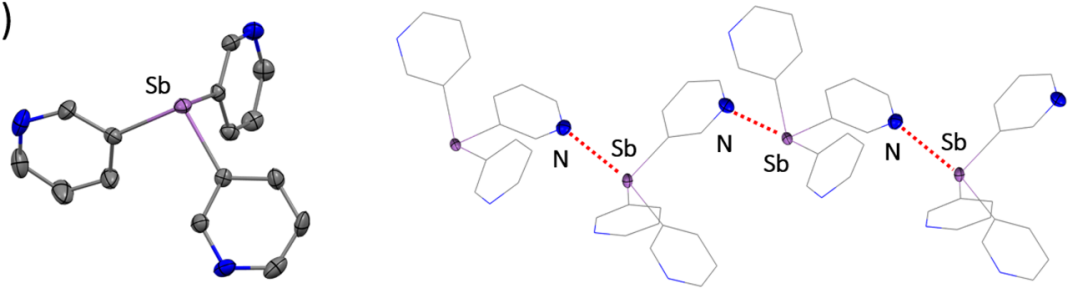

b)
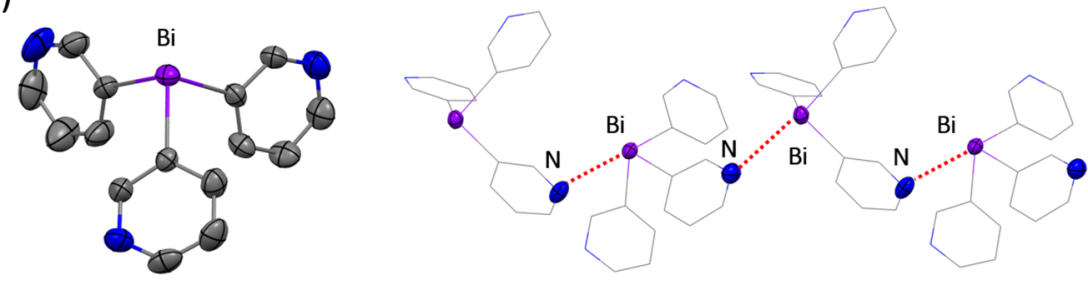

Figure 3. (a, left) Molecular structure of the monomeric unit of $\mathbf{1}$. (a, right) Formation of a zigzag-type structure in the crystal lattice through $\mathrm{Sb}$... $\mathrm{N}$ interactions between the monomeric units $\left[\mathrm{Sb} \cdots \mathrm{N} 3.355(4)-3.452(4) \AA \AA \text {; cf. } 3.61 \AA \text { for } \sum_{\mathrm{VDW}}(\mathrm{Sb} \cdots \mathrm{N})\right]^{39,40}$ (b, left) Molecular structure of the monomeric unit of 2. (b, right) Formation of a zigzag-type structure in the crystal lattice through $\mathrm{Bi} \cdots \mathrm{N}$ interactions between the monomeric units $\left[\mathrm{Bi} \cdots \mathrm{N} 3.374\right.$ (4) $\AA$; cf. $3.62 \AA$ for $\left.\sum_{\mathrm{VDW}}(\mathrm{Bi}-\mathrm{N})\right]$. Displacement ellipsoids at $50 \%$ probability. $\mathrm{H}$ atoms and a second independent molecule of 1 present in the asymmetric unit are omitted for clarity. Selected bond lengths $(\AA)$ and angles (deg) for 1: $S b-C_{p y}$ range $2.149(4)-2.160(4) ; C_{p y}-$ $\mathrm{Sb}-\mathrm{C}_{\mathrm{py}}$ range 91.3(1)-98.5(2). Selected bond lengths $(\AA)$ and angles $(\mathrm{deg})$ for 2: $\mathrm{Bi}-\mathrm{C}_{\mathrm{py}}$ range 2.249(4)-2.261(4); $\mathrm{C}_{\mathrm{py}}-\mathrm{Bi}-\mathrm{C}_{\mathrm{py}}$ range $90.5(1)-$ 96.3(1). Color key: C, gray; Sb, light purple; Bi, purple; N, blue.

a)

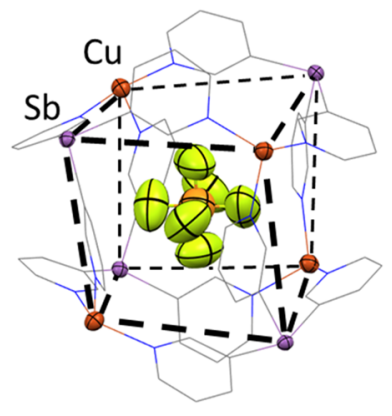

b)

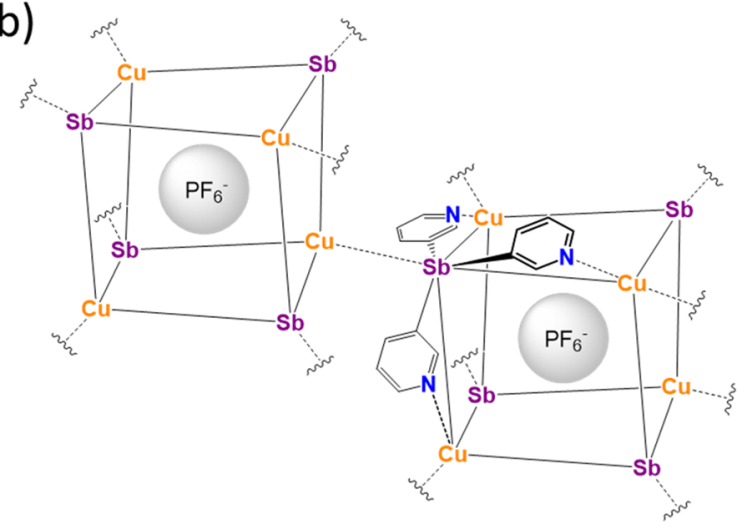

c)

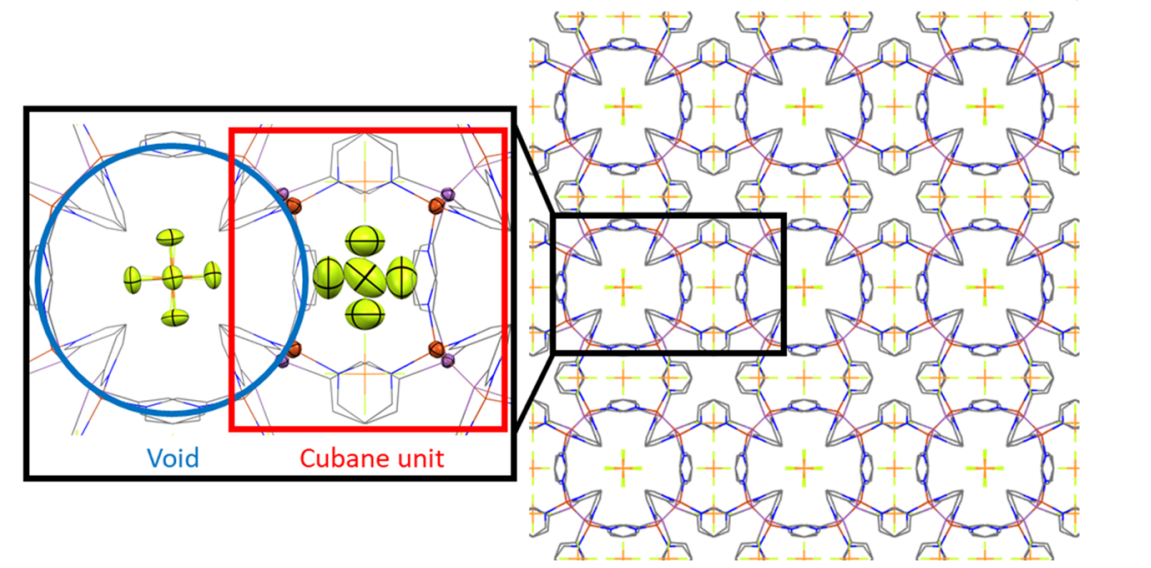

Figure 4. (a) Crystal structure showing the heterocubane monomeric unit $\left[\mathrm{Cu}(\mathbf{1})\left(\subset \mathrm{PF}_{6}\right)\right]^{3+}$ of the $3 \mathrm{D} \mathrm{MOF}\left[\mathbf{1}\left(\mathrm{CuPF}_{6}\right)\right]_{n}\left(\mathbf{1} \cdot \mathrm{CuPF}_{6}\right)$. This heterocubane unit consists of a cube in which $\mathrm{Sb}$ and $\mathrm{Cu}$ atoms are placed alternately at the vertices and linked together by a pyridine arm (edge). Displacement ellipsoids at $50 \%$ probability. $\mathrm{H}$ atoms and exo- $\mathrm{PF}_{6}$ are omitted for clarity. Selected bond lengths $(\AA)$ and angles $(\mathrm{deg}): \mathrm{Sb}-\mathrm{C}_{\mathrm{py}}$ $2.132(8) ; \mathrm{Cu}-\mathrm{N} 2.051(8) ; \mathrm{C}_{\mathrm{py}}-\mathrm{Sb}-\mathrm{C}_{\mathrm{py}} 98.7(5) ; \mathrm{N}-\mathrm{Cu}-\mathrm{N} 110.0(3)$. (b) Schematic representation of the formation of a polymeric 3D structure in the crystal lattice through $\mathrm{Sb}-\mathrm{Cu}$ interactions between the monomeric cubane units. (c) Wireframe X-ray structure along the $a, b$, or $c$ axes of the $3 \mathrm{D}$ structure of $\left[1\left(\mathrm{CuPF}_{6}\right)\right]_{n}$. The structure presents a network in which the cubane units (highlighted in red) and voids (highlighted in blue) alternate. One-fourth of the $\mathrm{PF}_{6}{ }^{-}$anions are found inside the cubanes, while the other three-fourths are located along the voids. Color key: $\mathrm{C}$, gray; $\mathrm{Cu}$, dark orange; $\mathrm{Sb}$, light purple; $\mathrm{N}$, blue; $\mathrm{P}$, orange; $\mathrm{F}$, yellow. 
Scheme 2. Synthesis of the Copper Complexes $1 \cdot \mathrm{CuX}\left(\mathrm{X}=\mathrm{BF}_{4}{ }^{-}, \mathrm{PF}_{6}{ }^{-}\right)$and the Silver Complexes $1 \cdot \mathrm{AgX}\left(\mathrm{X}=\mathrm{BF}_{4}{ }^{-}, \mathrm{PF}_{6}{ }^{-}\right.$, $\left.\mathrm{SbF}_{6}^{-}, \mathrm{OTf}^{-}\right)$

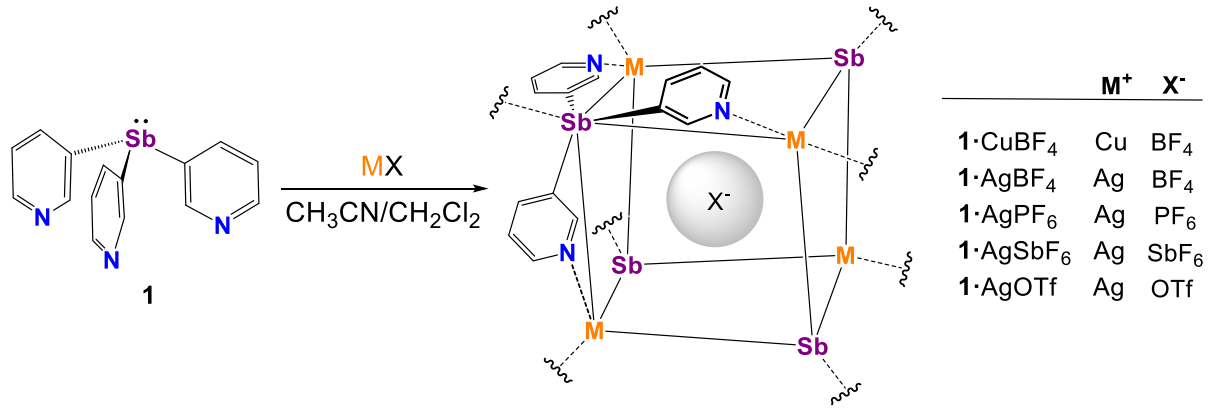

Table 1. (Top) Representation of the Key Angles and Distances for the Cubane Units in the Sb MOFs and (bottom) Key Cage Parameters for the Metal Cores of the $\mathrm{Cu}(\mathrm{I})$ and $\mathrm{Ag}(\mathrm{I})$ Complexes of Ligand 1

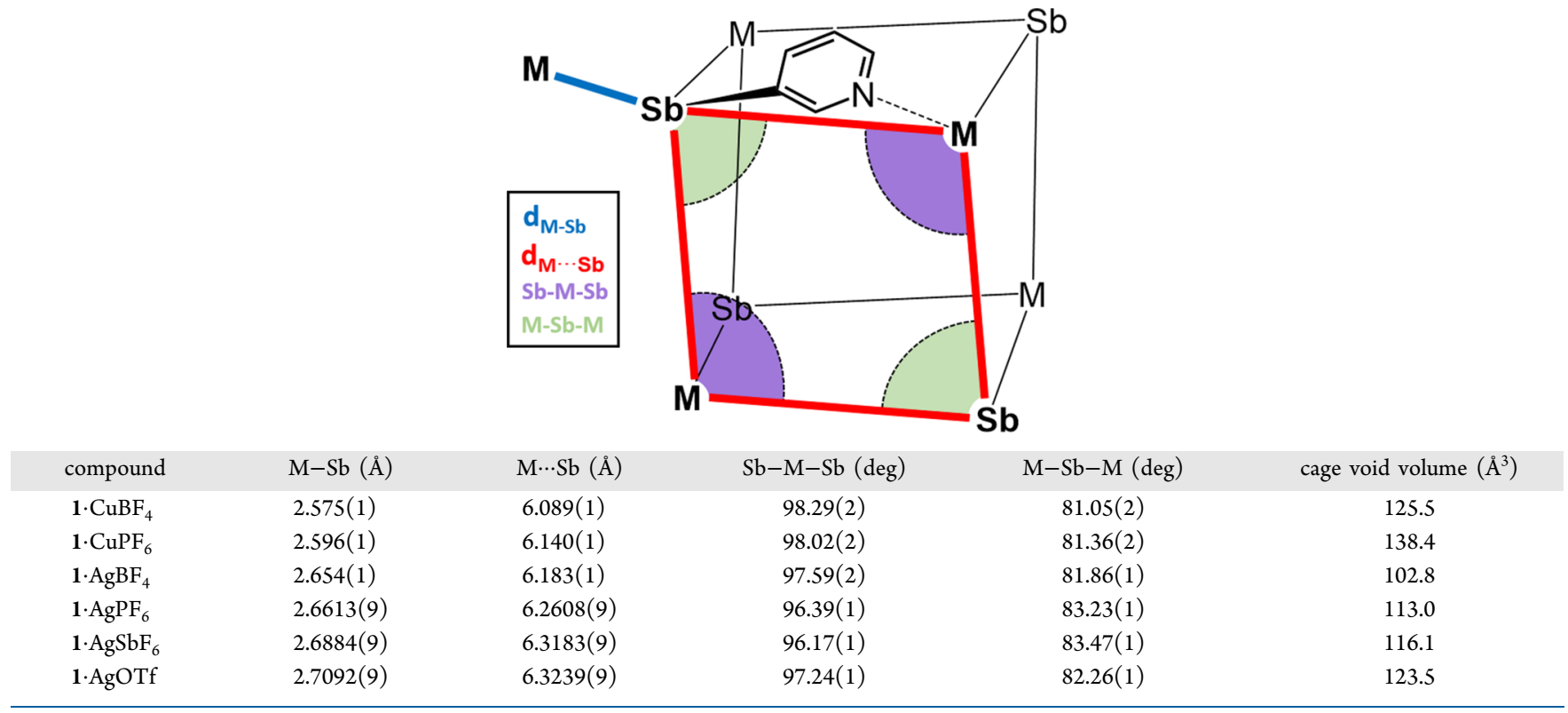

$\left.d_{6}\right)$ at room temperature, as monitored by ${ }^{1} \mathrm{H}$ NMR spectroscopy.

The single-crystal X-ray structures of both $\mathbf{1}$ and 2 are shown in Figure 3. As expected, molecules of 1 and 2 show pyramidal $\mathrm{Sb}$ (III) and $\mathrm{Bi}(\mathrm{III})$ centers. The more acute $\mathrm{C}-\mathrm{Bi}-$ $\mathrm{C}$ angles in $2\left[\mathrm{C}_{\mathrm{py}}-\mathrm{Bi}-\mathrm{C}_{\mathrm{py}}\right.$ range $\left.90.5(1)-96.3(1)^{\circ}\right]$ indicate somewhat more $\mathrm{p}$ character in the $\mathrm{C}-\mathrm{Bi}$ bonds and therefore higher $\mathrm{s}$ character in the metal lone pair compared to the $\mathrm{Sb}$ derivative $\left[\mathrm{C}_{\mathrm{py}}-\mathrm{Sb}-\mathrm{C}_{\mathrm{py}}\right.$ range $\left.91.3(1)-98.5(2)^{\circ}\right]$. Both species form $1 \mathrm{D}$ polymeric arrangements as a result of the association of molecules by short intermolecular $\mathrm{Sb} \cdots \mathrm{N}$ or $\mathrm{Bi} \cdots$ $\mathrm{N}$ contacts that are well below the sum of their van der Waals radii (Figure 3). However, the $\mathrm{Bi} \cdots \mathrm{N}$ interactions in $\mathbf{2}$ $[3.374(4) \AA]$ are significantly longer than those recently observed in the structure of $\mathrm{Bi}(4-\mathrm{py})_{3}$ [range $3.071(5)-$ $3.306(5) \AA]$, which also forms a polymeric arrangement in the solid state through $\mathrm{Bi} \cdots \mathrm{N}$ interactions. ${ }^{25}$

Coordination Chemistry. With ligands $\mathbf{1}$ and $\mathbf{2}$ in hand, we moved to explore their coordination chemistry and evaluate the impact of the bridgehead on building supramolecular arrangements. For this purpose, we focused on monovalent cations $\left(\mathrm{Cu}^{+}, \mathrm{Ag}^{+}\right.$, and $\left.\mathrm{Li}^{+}\right)$, which we hoped would facilitate simple comparisons on the basis of the ionic size alone. Studies of $\mathrm{Au}^{+}$proved to be unfruitful because the reactions of $\mathbf{1}$ and $\mathbf{2}$ with $\mathrm{AuCl}(\mathrm{THT})$ ( $\mathrm{THT}=$ tetrahydrothiophene) led to complete decomposition. In both cases, 3,3'-bipyridine was observed as a product along with a black precipitate (presumably containing metals; see the Supporting Information, SI).

The slow diffusion of a solution of $\left[\mathrm{Cu}(\mathrm{MeCN})_{4}\right] \mathrm{PF}_{6}(1$ equiv) in $\mathrm{MeCN}$ into a dichloromethane (DCM) solution of 1 over 1 week gave yellow blocks of the $3 \mathrm{D}$ MOF $\left[1\left(\mathrm{CuPF}_{6}\right)\right]_{n}$ $\left(1 \cdot \mathrm{CuPF}_{6}\right)$ in $79 \%$ yield (Figure 4$)$.The complex crystallizes in the cubic space group $P \overline{4} 3 n$. The $\mathrm{X}$-ray structure shows that four ligands 1 bridge four $\mathrm{Cu}(\mathrm{I})$ centers using all three pyridyl arms, forming a cationic $\left[\mathrm{Cu}_{4} \mathrm{Sb}_{4}\left(\subset \mathrm{PF}_{6}\right)\right]^{3+}$ heterocubane unit in which a $\mathrm{PF}_{6}^{-}$ion is encapsulated (Figure 4a). No short contacts were observed between this $\mathrm{PF}_{6}^{-}$ion and the surrounding shell of the cage units. These units are isostructural with the discrete cationic cage $[\{\mathrm{PhSn}(3-$ py $\left.\left.)_{3}\right\}_{4}(\mathrm{Cu} \cdot \mathrm{MeCN})_{4}\left(\subset \mathrm{PF}_{6}\right)\right]^{3+}$ noted previously (Figure 2$) .^{34}$ However, because the $\mathrm{Sb}$ center of 1 possesses a lone pair [rather than being blocked by a Ph group, as in the case of the $\mathrm{PhSn}(3 \text {-py })_{3}$ ligand], it is now able to coordinate to a $\mathrm{Cu}(\mathrm{I})$ ion of an adjacent cubane unit (Figure $4 \mathrm{~b}$ ). This results in the formation of a 3D MOF in which each cubane is linked to eight surrounding cubane units by $\mathrm{Sb}-\mathrm{Cu}$ bonds, with the $\mathrm{Sb}$ and $\mathrm{Cu}$ centers both being four-coordinated (Figure 4c). The $\mathrm{Sb}-\mathrm{Cu}$ bond lengths $[2.596(1) \AA]$ are comparable to the sum of the covalent radii $(2.52-2.71 \AA \text { for } \mathrm{Sb}-\mathrm{Cu})^{41,42}$ and are 
similar to the donor-acceptor bonds found in stibine-copper complexes, e.g., $\left[\mathrm{Cu}\left(\mathrm{SbPh}_{3}\right)_{4}\right]\left[\mathrm{ClO}_{4}\right](2.572-2.577 \AA){ }^{43}$ The connection of the cubane units produces a cationic sublattice in which voids are formed between the cubane units in which the remaining $\mathrm{PF}_{6}^{-}$anions are located.

After 1 week of exposure to air, no loss of crystallinity was observed for $\mathbf{1} \cdot \mathrm{CuPF}_{6}$, and measurement by single-crystal $\mathrm{X}$ ray diffraction showed that no degradation had occurred, demonstrating its stability in the solid state against $\mathrm{H}_{2} \mathrm{O}$ and $\mathrm{O}_{2}$. Although $\mathbf{1} \cdot \mathrm{CuPF}_{6}$ is not soluble in common organic solvents (THF, $\mathrm{CH}_{2} \mathrm{Cl}_{2}$, methanol, DMSO, etc.), it is slightly soluble in strongly coordinating pyridine, in which it breaks down into free ligand 1, as observed by NMR spectroscopy.

Effect of Other Anions. In order to explore the possible templating effect of the $\mathrm{PF}_{6}{ }^{-}$anion on the formation of $\mathbf{1}$. $\mathrm{CuPF}_{6}$, the coordination chemistry of $\mathbf{1}$ was investigated with a range of $\mathrm{CuX}\left(\mathrm{X}=\mathrm{BF}_{4}^{-}\right)$and $\mathrm{AgX}\left(\mathrm{X}=\mathrm{SbF}_{6}^{-} \mathrm{PF}_{6}^{-}, \mathrm{BF}_{4}^{-}\right.$, $\mathrm{CF}_{3} \mathrm{SO}_{3}{ }^{-}$) salts using 1:1 stoichiometries (Scheme 2). The new $\mathrm{Cu}(\mathrm{I})$ complex $\mathbf{1} \cdot \mathrm{CuBF}_{4}$ and $\mathrm{Ag}(\mathrm{I})$ complexes $\mathbf{1} \cdot \mathrm{AgSbF}_{6}$,

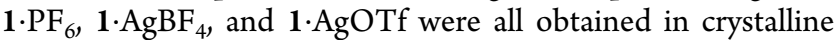
form and characterized by X-ray crystallography (see the SI and Scheme 2). All of the compounds are isostructural, showing the same MOF arrangement as that seen in $1 \cdot \mathrm{CuPF}_{6}$. The bulk and crystalline materials were confirmed to be identical for all of the complexes by powder X-ray diffraction (PXRD) and elemental analysis (see the Experimental Section and $\mathrm{SI}$ ).

Table 1 shows the key cage parameters of the compounds for comparison (including those previously discussed for $\mathbf{1}$. $\left.\mathrm{CuPF}_{6}\right)$. The $\mathrm{Ag}-\mathrm{Sb}$ distances linking the cage units in compound 1·AgX [range 2.654(1)-2.7092(9) $\AA$ ] are within the sum of the covalent radii (cf. $2.68-2.84 \AA$ for $\sum_{\text {cov }}$ ) and consistent with donor-acceptor interactions, like those found in $\left[\mathrm{Ag}\left(\mathrm{SbPh}_{3}\right)_{4}\right]\left[\mathrm{BF}_{4}\right]$ [average $\left.2.724(\AA)\right]^{44}$ A common feature of the $\mathrm{Sb}_{4} \mathrm{M}_{4}$ cubane units of the complexes of 1 is their rhombohedral arrangement (formed by six identical, almost planar $\mathrm{Sb}_{2} \mathrm{M}_{2}$ parallelograms of equal $\mathrm{Sb} \cdots \mathrm{M}$ length; Figure 5c). An interesting observation from these data is that the void volumes of the cage units (range 102.8-138.4 $\AA^{3}$ ) largely correlate with the quantum-chemical-calculated volumes of the encapsulated ions within each series (1. $\mathrm{CuX}$ and $\mathbf{1} \cdot \mathrm{AgX})$, i.e., smallest for $\mathrm{BF}_{4}^{-}\left(V=53.4 \AA^{3}\right)$ and largest for $\mathrm{PF}_{6}^{-}\left(73.0 \AA^{3}\right)$, OTf $-\left(86.9 \AA^{3}\right)$, and $\mathrm{SbF}_{6}^{-}\left(88.7 \AA^{3}\right)^{45}$ (see the SI). Indeed, for $1 \cdot \mathrm{AgX}$, a linear relationship is observed between the cage and anion volumes for all of the anions apart from the prolate OTf $^{-}$anion (which should, according to this correlation, have an anion volume closer to $105 \AA^{3}$ ). The observation of the same hybrid MOF structure for all of these compounds using a broad range of weakly coordinating $\left(\mathrm{BF}_{4}^{-}, \mathrm{PF}_{6}^{-}, \mathrm{SbF}_{6}^{-}\right)$and more strongly coordinating ( $\mathrm{OTf}^{-}$) anions suggests that, although there may be some aspect of anion templating involved, the primary structural direction is the ligand $\mathbf{1}$ itself and its ability to adopt the N,N,N/Sb-coordination mode.

In contrast to the $\mathrm{Sb}$ (III) bridgehead atom, $\mathrm{Bi}(\mathrm{III})$ is less donating and has greater Lewis acidity. We anticipated that this might translate into a stronger interaction with the anions in the case of ligand 2, promoting N,N,N-tridentate donor behavior by blocking the ability of the $\mathrm{Bi}$ lone pair to donate to metal ions. However, the reaction of $\left[\mathrm{Cu}(\mathrm{MeCN})_{4}\right] \mathrm{PF}_{6}$ and $\mathrm{AgSbF}_{6}$ with 2 resulted in the 3D MOF structures $\mathrm{Bi}(\mathrm{III}) /$ $\mathrm{Cu}(\mathrm{I})\left(\mathbf{2} \cdot \mathrm{CuPF}_{6}\right)$ and $\mathrm{Bi}(\mathrm{III}) / \mathrm{Ag}(\mathrm{I})\left(\mathbf{2} \cdot \mathrm{AgSbF}_{6}\right)$, which are closely related to those of ligand $\mathbf{1}$ (Scheme 3 and Figure 5). a)

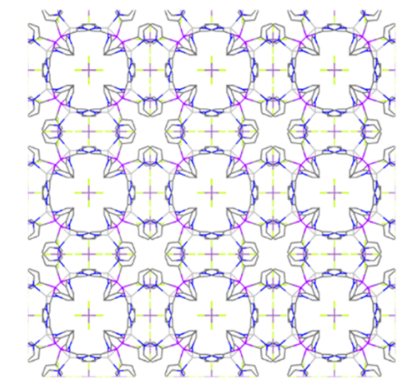

b)
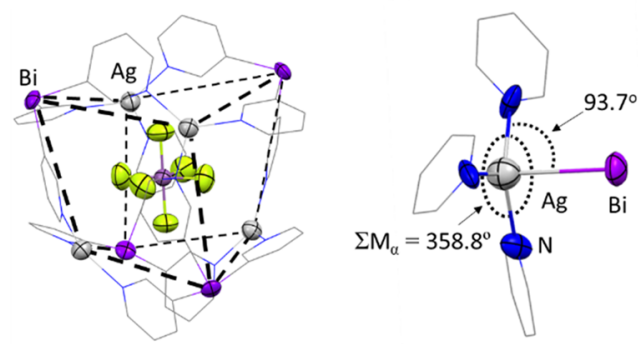

c)

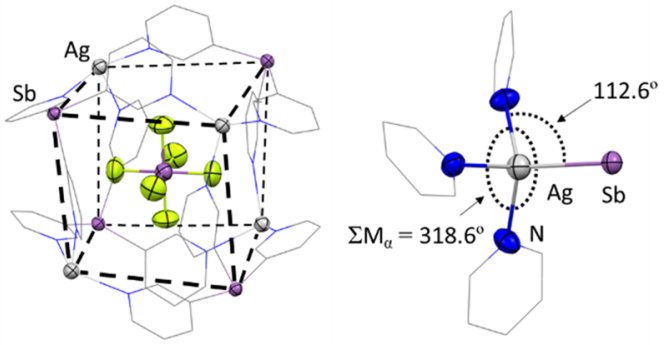

Figure 5. (a) Wireframe view along the $a, b$, or $c$ axis of the $3 \mathrm{D}$ structure of $2 \cdot \mathrm{AgSbF}_{6}$, which consists of a $3 \mathrm{D}$ arrangement of $\left[2\left(\mathrm{AgSbF}_{6}\right)\right]_{n}$. The structure presents a network in which the $\mathrm{Bi}_{4} \mathrm{Cu}_{4}$ heterocubane units and the voids are occupied by $\mathrm{SbF}_{6}{ }^{-}$anions $(1: 3$ cage/void ratio). Parts $\mathrm{b}$ and $\mathrm{c}$ show a comparison of the Bi complex $2 \cdot \mathrm{AgSbF}_{6}$ and its $\mathrm{Sb}$ analogue $1 \cdot \mathrm{AgSbF}_{6}$. (b, left) X-ray structure fragment showing the cubane unit of the compound $2 \cdot \mathrm{AgSbF}_{6}$. The front and back faces are outlined with dashed lines as a guide to the eye. (b, right) $\mathrm{X}$-ray structure fragment showing the $\mathrm{N}-\mathrm{Ag}-\mathrm{Sb}$ angle. (c, left) X-ray structure fragment showing the cubane unit of 1 . $\mathrm{AgSbF}_{6}$. The front and back faces are outlined with blue and red dashed lines, respectively. (c, right) X-ray structure fragment showing the $\mathrm{N}-\mathrm{Ag}-\mathrm{Sb}$ angle. Displacement ellipsoids at $50 \%$ probability. $\mathrm{H}$ atoms are omitted for clarity. Color key: $\mathrm{C}$, gray; $\mathrm{Ag}$, light gray; $\mathrm{Sb}$, light purple; N, blue; Bi, purple; F, yellow.

Despite the topological similarity of the MOFs formed with the $\mathrm{Sb}$ ligand $\mathbf{1}$ and the $\mathrm{Bi}$ ligand $\mathbf{2}$, the cage constituents of $\mathbf{2}$. $\mathrm{CuPF}_{6}$ and $2 \cdot \mathrm{AgSbF}_{6}$ are markedly more distorted than those of their counterparts $1 \cdot \mathrm{CuPF}_{6}$ and $\mathbf{1} \cdot \mathrm{AgSbF}_{6}$. This can be seen from a comparison of the data in Table 2 , which summarizes the key metal core parameters for $2 \cdot \mathrm{CuPF}_{6}$ and $2 \cdot \mathrm{AgSbF}_{6}$, with those in Table 1. Whereas the $\mathrm{Sb}_{4} \mathrm{M}_{4}$ cores of the $\mathrm{Cu}(\mathrm{I})$ and $\mathrm{Ag}(\mathrm{I})$ complexes of $\mathbf{1}$ are almost cubic (Figure 5c, left), the $\mathrm{Bi}_{4} \mathrm{M}_{4}$ metal cores of $2 \cdot \mathrm{CuPF}_{6}$ and $2 \cdot \mathrm{AgSbF}_{6}$ are far more distorted, with each pair of opposite (puckered) rhombic faces of the units exhibiting a $90^{\circ}$ phase displacement (Figure $5 \mathrm{~b}$, left). This greater distortion is largely the result of the rather unusual, almost planar coordination of the pyridyl $\mathrm{N}$ atoms to the $\mathrm{Cu}(\mathrm{I})$ and $\mathrm{Ag}(\mathrm{I})$ centers (Figure 5b, right), in contrast to the pyramidal coordination by the pyridyl $\mathrm{N}$ atoms of the metal $\mathrm{Cu}$ and $\mathrm{Ag}$ in all of the previous compounds of ligand 1 (Figure 5c, right). This is seen from the sums of the N-M-N bond angles $\left(\sum \mathrm{M}_{\alpha}, \mathrm{M}=\mathrm{Cu}, \mathrm{Ag}\right)$, which are very close to $360^{\circ}$ 
Scheme 3. Synthesis of the Bismuthine-Based Copper and Silver Complexes $2 \cdot \mathrm{CuPF}_{6}$ and $2 \cdot \mathrm{AgSbF}_{6}{ }^{a}$

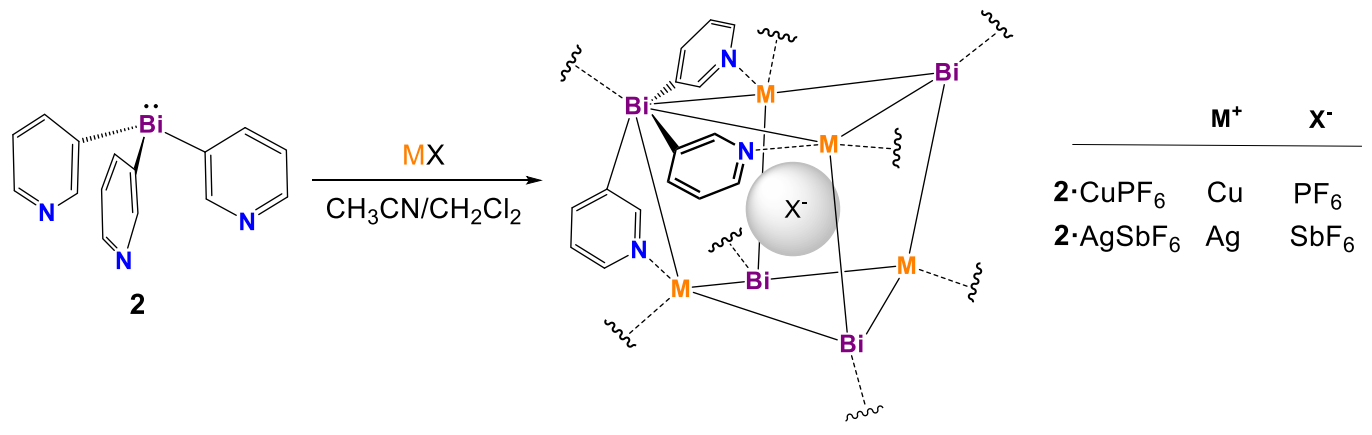

${ }^{a}$ Ligand 2 exhibits tetrapodal coordination using a N,N,N/Bi-coordination mode, and each $\mathrm{Bi}$ atom is coordinated to a metal, so that each metal is four-coordinate.

Table 2. Key Cage Parameters for the Metal Cores of 2 . $\mathrm{CuPF}_{6}$ and $2 \cdot \mathrm{AgSbF}_{6}{ }^{a}$

\begin{tabular}{lccccc} 
compound & $\mathrm{M}-\mathrm{Bi}(\AA)$ & $\mathrm{M} \cdots \mathrm{Bi}(\AA)$ & $\begin{array}{c}\mathrm{Bi}-\mathrm{M}-\mathrm{Bi} \\
(\mathrm{deg})\end{array}$ & $\begin{array}{c}\mathrm{M}-\mathrm{Bi}-\mathrm{M} \\
(\mathrm{deg})\end{array}$ & $\begin{array}{c}\text { cage void } \\
\text { volume } \\
\left(\AA^{3}\right)\end{array}$ \\
\hline $\mathbf{2} \cdot \mathrm{CuPF}_{6}$ & $3.041(2)$ & $6.065(2)$ & $107.10(2)$ & $69.60(2)$ & 116.6 \\
$\mathbf{2}^{-\mathrm{AgSbF}_{6}}$ & $3.178(2)$ & $6.260(3)$ & $108.73(4)$ & $67.14(3)$ & 109.9
\end{tabular}

${ }^{a}$ The definitions of key angles and distances are analogous to those of the $\mathrm{Sb}$ MOFs (Table 1).

$\left(\sum \mathrm{M}_{\alpha}=356.7^{\circ}\right.$ and $358.8^{\circ}$ for $2 \cdot \mathrm{CuPF}_{6}$ and $2 \cdot \mathrm{AgSbF}_{6}$, respectively; cf. $\sum \mathrm{M}_{\alpha}=330.0^{\circ}$ and $318.6^{\circ}$ for $\mathbf{1} \cdot \mathrm{CuPF}_{6}$ and $\mathbf{1}$. $\mathrm{AgSbF}_{6}$, respectively). This planar $\mathrm{N}$ coordination and the presence of shorter $\mathrm{Cu}-\mathrm{N}[1.987(6) \AA]$ and $\mathrm{Ag}-\mathrm{N}[2.21(2)$ $\AA$ ] bonds in $2 \cdot \mathrm{CuPF}_{6}$ and $2 \cdot \mathrm{AgSbF}_{6}$, respectively, compared to those in their counterparts $1 \cdot \mathrm{CuPF}_{6}$ and $\mathbf{1} \cdot \mathrm{AgSbF}_{6}[2.051(8)$ and $2.305(8) \AA$, respectively], are symptomatic of the weakness of the $\mathrm{Bi}-\mathrm{Cu}$ and $\mathrm{Bi}-\mathrm{Ag}$ bonds compared to the $\mathrm{Sb}-\mathrm{Cu}$ and $\mathrm{Sb}-\mathrm{Ag}$ bonds. This is an expected consequence of the relativistic stabilization of the $6 s^{2}$ lone pair on $\mathrm{Bi}$ (compared to the greater degree of $s-p$ mixing of the lone pair on the $\mathrm{Sb}$ analogue), making the Bi ligand 2 a weaker $\sigma$ donor [as confirmed by density functional theory (DFT) calculations, discussed later]. A further potential reason for distortion of the cage units of $2 \cdot \mathrm{CuPF}_{6}$ and $2 \cdot \mathrm{AgSbF}_{6}$ is the significantly smaller ligand bite angle of the $\mathrm{Bi}$ ligands 2 compared to 1 [e.g., $\mathrm{C}-\mathrm{Bi}-\mathrm{C} 94.3(3)-93.9(8)^{\circ}$ in $2 \cdot \mathrm{CuPF}_{6}$ and $2 \cdot \mathrm{AgSbF}_{6}$; cf. $98.7(3)-100.4(3)^{\circ}$ in $\mathbf{1} \cdot \mathrm{CuPF}_{6}$ and $\mathbf{1}$. $\mathrm{AgSbF}_{6}$ ]. It can be noted that there are few examples of $\mathrm{Bi}-$ $\mathrm{Cu}-$ and $\mathrm{Bi}-\mathrm{Ag}$-bonded compounds known in which $\mathrm{Bi}$ behaves as an L-type $\sigma$ donor. In fact, closed-shell $\mathrm{Bi}$ interactions with late transition metals have been almost completely unexplored, with only a few examples using the $\mathrm{PBiP}$ pincer ligands $(\mathrm{P}=$ phenylenephosphino groups) reported by Gabbai and Limberg, which place the Bi center in close proximity to the metal. ${ }^{46,47}$ Compared to these systems, $2 \cdot \mathrm{CuPF}_{6}$ possesses a similar $\mathrm{Bi}-\mathrm{Cu}$ bond length but is an example of an unsupported $\mathrm{Bi}-\mathrm{Cu}$ bond. The $\mathrm{Bi}-\mathrm{Cu}$ distance of 3.041(2) $\AA$ is at the upper limit of the $\mathrm{Bi}-\mathrm{Cu}$ bond distances reported by Gabbai and Limberg (2.790-3.095 $\AA)^{48-50}$ and lies between the sum of the van der Waals and covalent radii (cf. $3.47 \AA$ for $\sum_{\mathrm{VDW}}$ and 2.63-2.80 $\AA$ for $\sum_{\text {cov }}$ ). Similarly, the $\mathrm{Bi}-\mathrm{Ag}$ distance in $2 \cdot \mathrm{AgSbF}_{6}[3.178(2) \AA]$ lies between the sum of the van der Waals and covalent radii (cf. $3.79 \AA$ for $\sum_{\mathrm{VDW}}$ and $2.63-2.80 \AA$ for $\sum_{\mathrm{cov}}$ ) and is comparable to that reported by Gabbai and Limberg using their pincer ligands $(2.946-3.173 \AA) .{ }^{48-50}$
Computational Analysis. The interaction between the Ag and $\mathrm{Bi}$ atoms in $2 \cdot \mathrm{AgSbF}_{6}$ was studied using DFT. It should be kept in mind that the previously discussed extended 3D MOF structures are not amenable to simple calculational analysis. To approach this study with low computational cost, we employed a simple model by taking a fragment of the extended X-ray structure consisting of a $\left[\mathrm{Ag}(\mathrm{py})_{3}\right]^{+}$moiety attached to a $\mathrm{Bi}(3-$ py) $)_{3}$ ligand (see the SI). When free relaxation of the structure was allowed using the APFD functional, the minimum energy structure exhibited a $\mathrm{Ag}-\mathrm{Bi}$ distance of $2.655 \AA$ [very similar to that obtained with other functionals (see the SI) but shorter than that observed experimentally, 3.178(2) $\AA$ ]. The optimized structure shows pyramidalization of the Ag center $\left(\sum \mathrm{M}_{\alpha}=\right.$ $\left.341.4^{\circ}\right)$, in contrast to the planar geometry observed in the Xray structure $\left(\sum \mathrm{M}_{\alpha}=358.8^{\circ}\right)$. This suggests that there are other factors affecting the interaction between the $\mathrm{Ag}$ and $\mathrm{Bi}$ atoms. The structure was then optimized with the same (planar) geometry as that found in the X-ray structure of $\mathbf{2}$. $\mathrm{AgSbF}_{6}$ at the $\mathrm{Ag}$ center. The $\mathrm{Ag}-\mathrm{Bi}$ bond length was increased to $3.124 \AA$, which is in very good agreement with the experimental distance. The energy difference between the two models in which $\mathrm{Ag}$ is pyramidal or planar is very small (0.6 $\mathrm{kcal} / \mathrm{mol}$ ). Therefore, distortion of the geometry to a planar geometry at $\mathrm{Ag}$ observed in the solid-state structure is probably the result of packing effects alone. The freely optimized geometry exhibits a $\mathrm{Bi}-\mathrm{Ag}$ bond energy of $27.0 \mathrm{kcal} / \mathrm{mol}$, and the $\mathrm{X}$-ray structure model with the planar geometry at $\mathrm{Ag}$ shows a $\mathrm{Bi}-\mathrm{Ag}$ bond energy of $14.1 \mathrm{kcal} / \mathrm{mol}$, in accordance with the larger $\mathrm{Bi}-\mathrm{Ag}$ distance [both were calculated using an energy decomposition analysis (EDA) performed with the AOMIX program $].{ }^{51}$

The DFT calculations also show that the bismuthine ligand 2 acts as a $\sigma$ donor in the $\mathrm{Bi}-\mathrm{Ag}$ bonding. In order to identify which orbitals are involved, a natural bonding orbital (NBO) analysis was carried out on the $\mathrm{X}$-ray structure model. The study indicated one main interaction between the filled lone pair on $\mathrm{Bi}\left[6 \mathrm{~s}(80 \%)-6 \mathrm{p}_{z}(20 \%)\right]$ and the empty atomic orbital of $\mathrm{Ag}$ [5s (98\%)]. No donation from $\mathrm{Ag}$ to $\mathrm{Bi}$ was identified, indicating that bismuth does not act as an acceptor. Similar calculations using a model system for the X-ray geometry of $\mathbf{1} \cdot \mathrm{AgSbF}_{6}$ show that the $\mathrm{Sb}-\mathrm{Ag}$ interaction is much stronger (35.2 vs $14.1 \mathrm{kcal} / \mathrm{mol}$ for $\mathrm{Bi}-\mathrm{Ag}$ ) and results from one main interaction between the filled lone pair on $\mathrm{Sb}$ $\left[5 \mathrm{~s}(66 \%)-5 \mathrm{p}_{z}(34 \%)\right]$ and the empty atomic orbital of $\mathrm{Ag}[5 \mathrm{~s}$ $(100 \%)]$. Thus, the weakness of the $\mathrm{Bi}-\mathrm{Ag}$ bond provides an explanation for the observed and unusual planarity of the $\mathrm{Ag}$ center in $\mathbf{2} \cdot \mathrm{AgSbF}_{6}$ and the pyramidalization of the $\mathrm{Ag}$ center 
a)

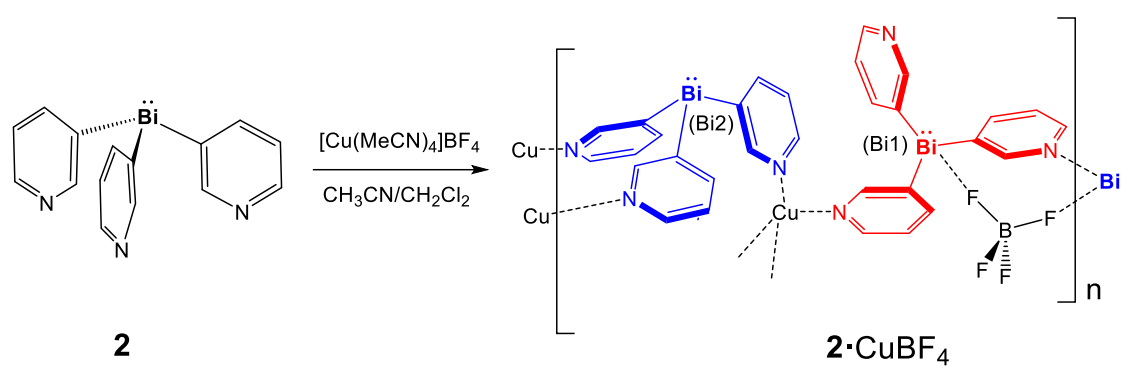

b)

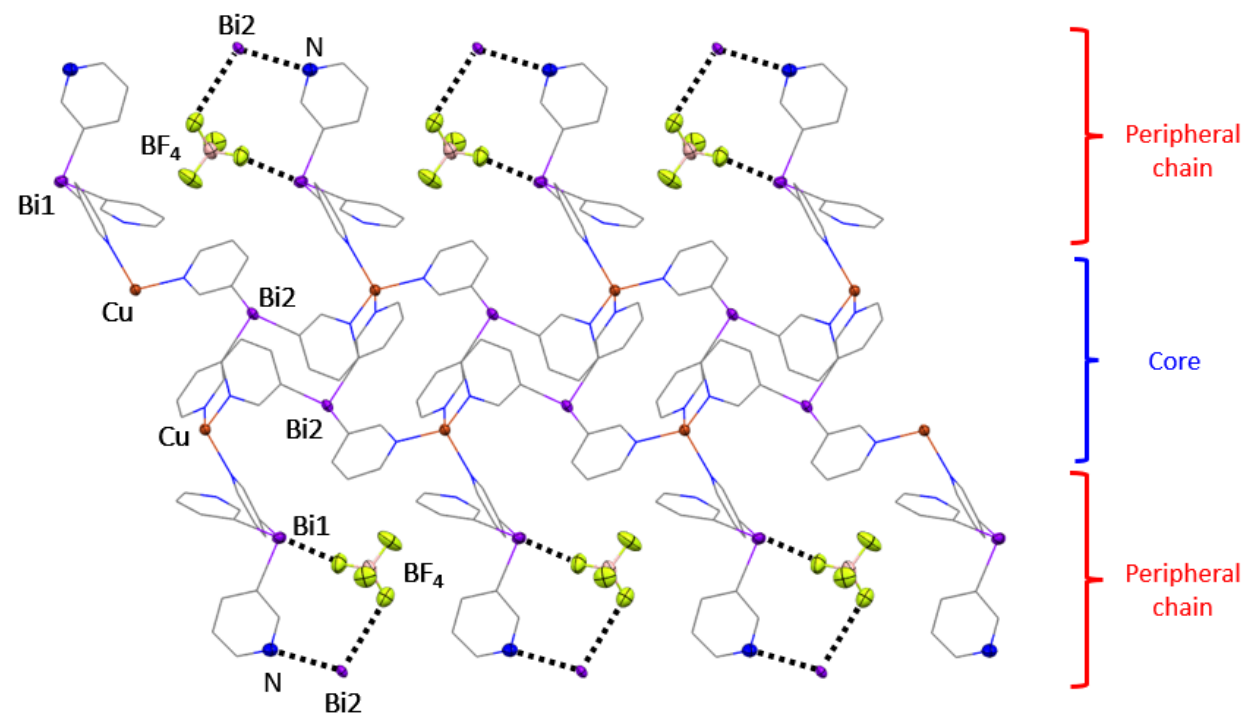

Figure 6. (a) Synthesis of $2 \cdot \mathrm{CuBF}_{4}$. (b) X-ray structure of the extended $1 \mathrm{D}$ coordination polymer of $2 \cdot \mathrm{CuBF}_{4} \cdot \mathrm{H}$ atoms and some of the $\mathrm{BF}_{4}{ }^{-}$ anions in the lattice (those located in the core) are omitted for clarity. Selected bond lengths $(\AA)$ and angles $(\mathrm{deg}): \mathrm{Bi}-\mathrm{C}_{\mathrm{py}} 2.26(1)-2.29(1) ; \mathrm{Cu}-$ $\mathrm{N} 2.03(1)-2.07(1) ; \mathrm{C}_{\mathrm{py}}-\mathrm{Bi}-\mathrm{C}_{\mathrm{py}}$ 91.1(5)-95.3(5); N-Cu-N 105.7(4)-114.9(4). Color key: C, gray; Cu, orange; N, blue; Bi, purple; B, pink; F, yellow.

in $\mathbf{1} \cdot \mathrm{AgSbF}_{6}$. Similar DFT studies show that the same tendency is maintained in the $\mathrm{Cu}$ structures, with stronger $\mathrm{Sb}-\mathrm{Cu}$ interaction ( $34.2 \mathrm{kcal} / \mathrm{mol}, 69 \% 5 \mathrm{~s}+31 \% 5 \mathrm{p} \rightarrow 100 \% 5 \mathrm{~s})$ relative to the $\mathrm{Bi}-\mathrm{Cu}$ interaction $(15.0 \mathrm{kcal} / \mathrm{mol}, 79 \% 6 \mathrm{~s}+$ $21 \% 6 \mathrm{p} \rightarrow 98 \% 5 \mathrm{~s}$ ); thus, similarly to the Ag complexes, the planarity $\mathrm{Cu}^{+}$in $2 \cdot \mathrm{CuPF}_{6}$ can be related to the weak $\mathrm{Bi}-\mathrm{Cu}$ bond. The DFT studies reflect the reluctance of $\mathrm{Bi}$ to engage in $s-p$ mixing, which, along with the weaker nature of the $\mathrm{M}-\mathrm{Bi}$ interaction, provides an explanation for the differences in the $\mathrm{Bi}$-based MOFs compared to the $\mathrm{Sb}$ ones and suggests that the $\mathrm{Sb}$ ligand 1 should have a larger structure-directing influence than the Bi ligand 2. It is obvious that the different bridgeheads may lead to very different geometric profiles for the $\mathrm{E}(3-\mathrm{py})_{3}$ ligands, but changing the bridgehead can also have large electronic implications. This feature has also recently been highlighted in a study of the formation of $2 \mathrm{D}$ or $3 \mathrm{D}$ networks using Group 15 tris(4-pyridyl) ligands. ${ }^{25}$

Preliminary studies indicate that the bridgehead-metal interaction also has a large impact on the luminescence properties of the 3D MOFs. For instance, when excited with UV light $\left(\lambda_{\text {ex }}=375 \mathrm{~nm}\right)$ at room temperature, the $\mathrm{Bi}(\mathrm{III}) /$ $\mathrm{Cu}(\mathrm{I}) \mathrm{MOF} 2 \cdot \mathrm{CuPF}_{6}$ exhibits bright-green luminescence $\left(\lambda_{\text {max }, \mathrm{em}}=530 \mathrm{~nm}\right)$, while its $\mathrm{Sb}$ analogue $1 \cdot \mathrm{CuPF}_{6}$ shows red-shifted luminescence in the orange region $\left(\lambda_{\text {max }, \mathrm{em}}=570\right.$ $\mathrm{nm}$; see the SI). In both cases, the solid-state photoluminescence emission spectra appear as broad featureless bands. Interestingly, the emission spectra of $1 \cdot \mathrm{CuPF}_{6}$ and 1 . $\mathrm{CuBF}_{4}$ are almost identical (see the SI), strongly suggesting that the Group 15- $\mathrm{Cu}$ bonding has a major influence on the luminescence and that the luminescence properties can be tuned by these interactions in the solid-state structures of the MOFs.

Effect of Bi-Anion Interactions. The structural effect of changing the bridgehead can be observed in the reaction of $\mathbf{2}$ with $\mathrm{CuBF}_{4}$. The 1:1 reaction leads to the formation of a $1 \mathrm{D}$ coordination polymer $\left[\mathrm{Cu}(\mathbf{2})_{2}\right]\left[\mathrm{BF}_{4}\right]\left(\mathbf{2} \cdot \mathrm{CuBF}_{4}\right)$ as yellow needle crystals (rather than cubic crystals as in the previous cases for the 3D MOFs). Although the complex contains a $1: 2$ ratio of ligand 2 to $\mathrm{CuBF}_{4}$, its formation is observed irrespective of the stoichiometry used $(1: 1$ or $1: 2)$, but the use of the required 1:2 stoichiometry leads to higher yields. The X-ray study reveals a complicated structure consisting of a 1D coordination polymer formed by three parallel chains in which no $\mathrm{Bi}$ coordination to the $\mathrm{Cu}(\mathrm{I})$ center is observed (Figure 6). In the central chain, bridging ligands 2 (Bi2 atom in Figure 6) link $\mathrm{Cu}(\mathrm{I})$ units into a polymeric arrangement 
a)

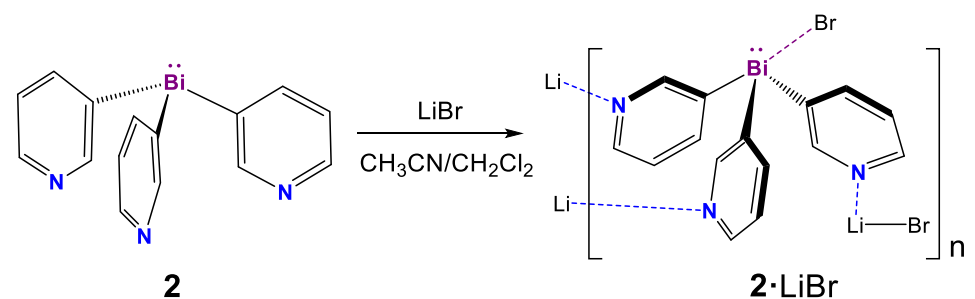

b)

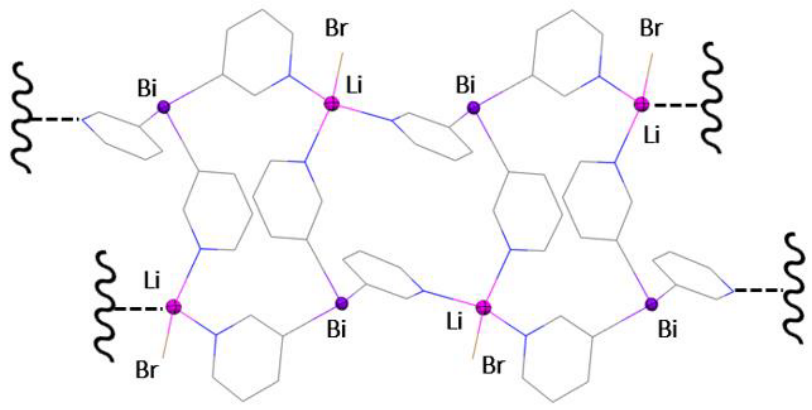

C)

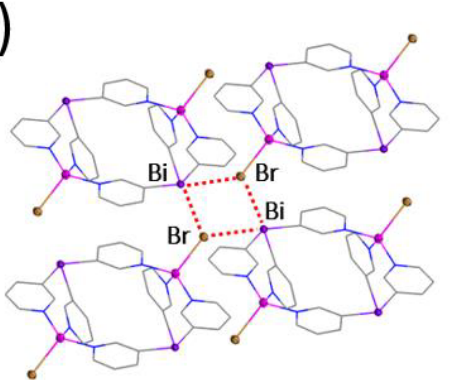

d)

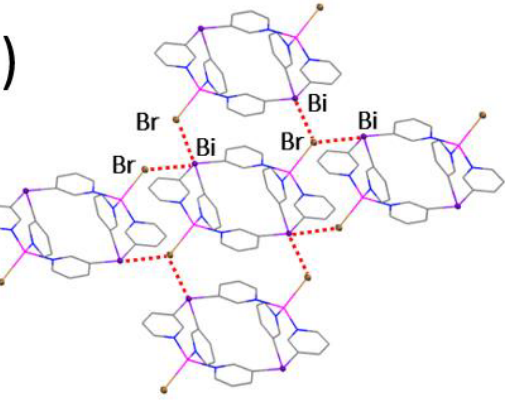

Figure 7. (a) Synthesis of $\mathbf{2} \cdot \mathrm{LiBr} \cdot \mathrm{MeCN}$. (b) X-ray structure of the $1 \mathrm{D}$ polymeric structure of $\mathbf{2} \cdot \mathrm{LiBr} \cdot \mathrm{MeCN}$, which is composed of fused $\mathrm{Li}{ }_{2} \mathrm{Bi}_{2}$ rings. (c) View along the $b$ axis and formation of the polymeric 3D structure resulting in short $\mathrm{Bi}-\mathrm{Br}$ interactions between adjacent chains (d). Displacement ellipsoids at $50 \%$ probability. $\mathrm{H}$ atoms and one molecule of $\mathrm{MeCN}$ present in the asymmetric unit are omitted for clarity. Selected bond lengths $(\AA)$ and angles (deg): $\mathrm{Bi}-\mathrm{C}_{\mathrm{py}} 2.256(4)-2.286(3) ; \mathrm{Li}-\mathrm{N} 2.050(7)-2.075(5) ; \mathrm{Li}-\mathrm{Br} 2.517(7) ; \mathrm{C}_{\mathrm{py}}-\mathrm{Bi}-\mathrm{C}_{\mathrm{py}} 91.8(1)-92.9(1) ; \mathrm{N}-$ $\mathrm{Li}-\mathrm{N}$ 104.3(3)-116.3(3). Color key: Br, brown; C, gray; Li, pink; Bi, purple; N, blue.

using all three $\mathrm{N}$-donor atoms and propagating the $1 \mathrm{D}$ coordination polymer. The two lateral $1 \mathrm{D}$ chains are linked to the central one by alternating coordination (above and below the central chain) to $\mathrm{Cu}(\mathrm{I})$ by molecules of 2 (Bil atom in Figure 6) using just one of the three 3-Py N-donor atoms to coordinate the fourth position of the $\mathrm{Cu}$ center; thus, all $\mathrm{Cu}$ atoms are four-coordinate. The other two pyridyl arms are uncoordinated, although one of the pyridine arms is involved in a short contact with a core $\mathrm{Bi}$ atom. The high Lewis acidity of the $\mathrm{Bi}$ bridgehead atoms is manifested through anion $\cdots \mathrm{Bi}$ interactions, which are particularly short for the peripheral $\mathrm{Bi}$ ligands $\left[\mathrm{Bi} \cdots \mathrm{F}\right.$ 3.104(9) $\AA$; cf. $3.54 \AA$ for $\left.\sum_{\mathrm{VDW}}(\mathrm{Bi} \cdots \mathrm{F})\right]$. The core $\mathrm{Bi}$ ligands also form $\mathrm{F}$-..Bi contacts, albeit much longer ones $[3.357(9) \AA]$, suggestive of weaker interactions.

While it is difficult to pinpoint the exact reasons for the switch in the structural type from the MOF arrangement found in the $\mathrm{CuBF}_{4}$ complex of $\mathbf{1}\left(\mathbf{1} \cdot \mathrm{CuBF}_{4}\right)$ and the $\mathrm{CuPF}_{6}$ complex of $2\left(2 \cdot \mathrm{CuPF}_{6}\right)$ to the $1 \mathrm{D}$ arrangement seen in the $\mathrm{CuBF}_{4}$ complex of $2\left(2 \cdot \mathrm{CuBF}_{4}\right)$, this is clearly an example of anion direction. Importantly, in this respect, the $\mathrm{Bi}(\mathrm{III})$ bridgehead of ligand $\mathbf{2}$ is significantly more Lewis acidic than the $\mathrm{Sb}$ (III) bridgehead of 1 , leading to an increased ability for anionbridgehead interactions. In short, the lower Lewis basicity of the $\mathrm{Bi}$ center leads to weaker $\mathrm{Bi}-$ metal bonding and stronger
anion-Bi interactions, which, if sufficiently strong, can divert the thermodynamics away from the MOF structure.

To explore the effect of the presence of more strongly coordinating anions, we studied the reactions of 2 with $\mathrm{CuBr}$ and $\mathrm{LiBr}$. Reaction with $\mathrm{CuBr}$ led to the formation of a yellow solid that was highly insoluble, precluding characterization. However, PXRD studies indicated a different outcome from that of the 3D MOFs discussed above (see the SI). LiBr was selected to explore the switch of the bridgehead from cation coordination to anion interaction. We reasoned that the hard $\mathrm{Li}^{+}$would suppress bridgehead coordination of the metal ion, while the strongly coordinating $\mathrm{Br}^{-}$would promote anion interaction, thus promoting $\mathrm{N}, \mathrm{N}, \mathrm{N}$ coordination to $\mathrm{Li}^{+}$and $\mathrm{Bi}-\mathrm{Br}$ coordination. The slow diffusion of a solution of $\mathrm{LiBr}(1$ equiv) in $\mathrm{MeCN}$ into a DCM solution of 2 ( 1 equiv) over 1 week gave colorless crystals of $\left[\mathrm{Bi}(3-\mathrm{py})_{3}(\mathrm{LiBr})(\mathrm{MeCN})\right]_{n}(\mathbf{2}$. $\mathrm{LiBr} \cdot \mathrm{MeCN}$; Figure 7). The X-ray structure consists of a $1 \mathrm{D}$ coordination polymer in which the bismuthine ligand $\mathbf{2}$ uses all three pyridine donor atoms to coordinate neighboring $\mathrm{LiBr}$ units, resulting in a distorted four-coordinate geometry for the $\mathrm{Li}$ atom. This leads to the formation of a ribbonlike polymeric arrangement composed of fused $\mathrm{Li}_{2} \mathrm{Bi}_{2}$ rings (Figure $7 \mathrm{a}$ ). The Lewis acidity of the bridgehead is expressed in the formation of short intermolecular $\mathrm{Bi} \cdots \mathrm{Br}$ contacts $[\mathrm{Bi} \cdots \mathrm{Br} 3.7272(5)$ and 
3.6922(4) $\AA$; cf. $3.9 \AA$ for $\left.\sum_{\mathrm{VDW}}(\mathrm{Bi} \cdots \mathrm{Br})\right]$ of all of the Bi(III) centers of the 1D chains, illustrating the amphiphilic character of the bismuthine ligand 2. Each Bi center interacts with two $\mathrm{Br}$ centers of two adjacent ribbons. An additional $\mathrm{Bi}$ atom completes a $\mathrm{Bi}_{2} \mathrm{Br}_{2}$ core (Figure $7 \mathrm{~b}$ ) linking a total of four ribbons; thus, each ribbon is engaged in a $3 \mathrm{D}$ structure surrounded by four ribbons (Figure 7c).

\section{CONCLUSIONS}

In conclusion, the tris(3-pyridyl) ligands $\mathrm{E}(3-\mathrm{py})_{3}[\mathrm{E}=\mathrm{Sb}(\mathbf{1})$, Bi (2)] form a common hybrid 3D MOF arrangement with an extensive range of $\mathrm{Cu}(\mathrm{I})$ and $\mathrm{Ag}(\mathrm{I})$ salts (containing different anions $\mathrm{X}$ ), composed of a cationic substructure of $\mathrm{E}_{4} \mathrm{M}_{4}$ cage constituents linked together by $\mathrm{E}-$ metal $(\mathrm{M})$ bonding. This suggests that the ligands themselves and their ability to function as tetrahedral N,N,N,E-bonding nodes have a major structure-directing influence. However, the stability of this MOF arrangement is subtly influenced by the balance between the Lewis basicity and acidity of the bridgehead atoms (E). In the case of the bismuthine ligand 2, the low accessibility of the lone pair on the Bi bridgehead results in inherently weak $\mathrm{Bi}-\mathrm{M}$ bonds and higher Lewis acidity than that in the stibene 1 . This means that anion - bridgehead interactions can compete with metal coordination, leading to collapse of the MOF structure in the case of complexes of $\mathbf{2}$ (as seen in $2 \cdot \mathrm{CuBF}_{4}$ or $\mathbf{2} \cdot \mathrm{LiBr}$. $\mathrm{MeCN}$ ). This work underlines how subtle electronic effects of the bridgehead can modulate the coordination behavior of these ligands and provides a step forward in both understanding and directing the formation of supramolecular complexes in this area.

\section{EXPERIMENTAL SECTION}

General Experimental Techniques. All syntheses were carried out on a vacuum line under a $\mathrm{N}_{2}$ atmosphere. Products were isolated and handled under a $\mathrm{N}_{2}$ atmosphere. 3-Bromopyridine, NMR solvents, and reaction solvents were stored over molecular sieves and degassed using three freeze-pump-thaw cycles under $\mathrm{N}_{2}$ prior to use. NMR spectra were recorded using a $500 \mathrm{MHz}$ Agilent DD2 instrument equipped with a cold probe and a $400 \mathrm{MHz}$ Agilent instrument equipped with a ONEPROBE in the Laboratory of Instrumental Techniques (LTI) Research Facilities, University of Valladolid. Chemical shifts $(\delta)$ are reported in parts per million (ppm). ${ }^{1} \mathrm{H}$ and ${ }^{13} \mathrm{C}$ NMR are referenced to tetramethylsilane. Coupling constants $(J)$ are reported in hertz. Standard abbreviations are used to indicate multiplicity: $\mathrm{s}=$ singlet, $\mathrm{d}=$ doublet, $\mathrm{t}=$ triplet, and $\mathrm{m}=$ multiplet. ${ }^{1} \mathrm{H}$ and ${ }^{13} \mathrm{C}$ peak assignments were performed with the help of additional 2D NMR experiments $\left({ }^{1} \mathrm{H}-{ }^{13} \mathrm{C}\right.$ HSQC and ${ }^{1} \mathrm{H}-{ }^{13} \mathrm{C}$ HMBC). High-resolution mass spectrometry (HR-MS) spectra were recorded at the mass spectrometry service of the Centros de Apoyo a la Investigación of the University of Alcalá and the LTI of the University of Valladolid. An Agilent TOF-LC/MS 6210 spectrometer [electrospray ionization time-of-flight (ESI-TOF), positive-ion mode], a UPLC-MS system [ultraperformance liquid chromatography (UPLC), Waters ACQUITY H-class ultraperformance liquid chromatograph; MS, Bruker Maxis Impact spectrometer) by ESI (positive-ion mode), a matrix-assisted laser desorption/ ionization time-of-flight (MALDI-TOF) system, and a Bruker autoflex speed $\left(\mathrm{N}_{2}\right.$ laser: $337 \mathrm{~nm}$, pulse energy $=100 \mu \mathrm{J}, 1 \mathrm{~ns}$, acceleration voltage $=19 \mathrm{kV}$, reflector positive mode $)$ were used. trans-2-[3-(4tert-Butylphenyl)-2-methyl-2-propenylidene]malonitrile was used as the matrix. Luminescence spectra were recorded at the University of Valladolid and the Parque Cientifico Tecnológico (PCT) facilities of the University of Burgos. A PerkinElmer LS-55 luminescence spectrometer and an Edinburgh FLS980 fluorescence spectrometer equipped with an integrating sphere module and a single-photon photomultiplier-tube detector were used. The emission lifetime of the solid samples was carried out with time-correlated single photon counting of the FLS980 spectrometer. All data were measured at 25 ${ }^{\circ} \mathrm{C}$. PXRD measurements were performed in the LTI of the University of Valladolid using a Bruker Discover D8 diffractometer. The PXRD patterns of all of the isolated compounds were coincident with those predicted by the software package MERCURY from singlecrystal X-ray analysis (see the Experimental Section), thus confirming the identity of the bulk products.

X-ray Diffraction Studies. Diffraction data were collected using an Oxford Diffraction Supernova diffractometer equipped with an Atlas CCD area detector and a four-circle $\kappa$ goniometer. For the data collection, a Mo-microfocused source with multilayer optics was used. When necessary, crystals were mounted directly from solution using perfluorohydrocarbon oil to prevent atmospheric oxidation, hydrolysis, and solvent loss. Data integration, scaling, and empirical absorption correction were performed using the CrysAlisPro software package. ${ }^{52}$ The structure was solved by direct methods and refined by full-matrix least squares against $F^{2}$ with $S H E L X^{53}$ in OLEX2. Non-H atoms were refined anisotropically, and $\mathrm{H}$ atoms were placed at idealized positions and refined using the riding model. Graphics were made with OLEX2 $2^{54}$ and MERCURY. ${ }^{55}$ In the case of $\mathbf{2} \cdot \mathrm{CuBF}_{4}$ and $\mathbf{2}$. $\mathrm{LiBr} \cdot \mathrm{MeCN}$, the data were collected using a D8 VENTURE dualsource configuration diffractometer with an a $\mathrm{I} \mu \mathrm{S} 3.0$ microfocus source of Mo by the staff at the PCT, University of Burgos. For measurement of the voids of the cages, first, the anion located in the cage was removed from the $\mathrm{X}$-ray structure. Once the anion was removed, the void volume $\left(\AA^{3}\right)$ values for the MOFs were calculated using the "Calculate solvent accessible voids" tool in OLEX2 using a probe radius of $1.2 \AA$ and a grid spacing of $0.1 \AA^{54}$

Computational Details. All computations were carried out using the Gaussian 16 package, ${ }^{56}$ in which the hybrid method of Austin, Petersson, and Frisch with spherical atom dispersion terms (APFD) was applied. ${ }^{57}$ The cc-pvtz-pp basis set was used for the $\mathrm{Ag}, \mathrm{Cu}, \mathrm{Bi}$, and $\mathrm{Sb}$ atoms, ${ }^{58-61}$ as found in the EMSL basis set exchange Web site $^{62}$ and the double- $\zeta$ 6-31G( $\left(\mathrm{d}^{\prime}\right)$ basis set with polarization functions was used for the rest of the atoms. Geometry optimizations were performed without any symmetry restrictions, using the initial coordinates derived from the X-ray data when available, and frequency analyses were performed to ensure that a minimum structure with no imaginary frequencies was achieved in each case. NBO analysis was carried out using the program NBO 7.0.10 $0^{63}$ and EDA with the help of the AOMIX program. ${ }^{31,64}$ Visualization of the calculation results was performed using GaussView 6.1. ${ }^{65}$

Synthesis of 1. 3-Bromopyridine $(0.96 \mathrm{~mL}, 10 \mathrm{mmol})$ was added dropwise over $30 \mathrm{~min}$ to a stirred solution of a $1.3 \mathrm{M}$ isopropylmagnesium chloride/lithium chloride complex in THF (7.7 mL, $10 \mathrm{mmol}, 1.3 \mathrm{M}$ in THF) at $-0{ }^{\circ} \mathrm{C}$. The resulting orange solution was stirred for $1 \mathrm{~h}$ at $0{ }^{\circ} \mathrm{C}$. A solution of $\operatorname{SbBr}_{3}(1.20 \mathrm{~g}, 3.33$ $\mathrm{mmol})$ in THF $(10 \mathrm{~mL})$ was added dropwise to the orange solution. The resulting mixture was allowed to reach room temperature. After overnight stirring, a colorless solution with a white precipitate was observed. All volatiles were removed under vacuum. DCM $(100 \mathrm{~mL})$ was added to the precipitate, and the resulting white suspension was treated with $\mathrm{H}_{2} \mathrm{O}(50 \mathrm{~mL} \times 3)$. The organic phase was dried over anhydrous magnesium sulfate. The suspension was filtered through Celite to yield a colorless solution, which was concentrated under vacuum, and slow diffusion of $n$-hexane $(20 \mathrm{~mL})$ at $-24{ }^{\circ} \mathrm{C}$ yielded 1 as white plates suitable for X-ray crystallography. Yield: $0.87 \mathrm{~g}(2.44$ mmol, 74\%). ${ }^{1} \mathrm{H}$ NMR (298 K, $\left.\mathrm{CDCl}_{3}, 500 \mathrm{MHz}\right): \delta 8.61\left(\mathrm{~m}, 6 \mathrm{H}, \mathrm{H}_{2}\right.$ $+\mathrm{H}_{6}$ py), 7.69 (dt, $J=1.8 / 7.7 \mathrm{~Hz}, 3 \mathrm{H}, \mathrm{H}_{4}$ py), 7.30 (m, 3H, $\mathrm{H}_{5}$ py). ${ }^{13} \mathrm{C}\left\{{ }^{1} \mathrm{H}\right\} \operatorname{NMR}\left(298 \mathrm{~K}, \mathrm{CDCl}_{3}, 100.6 \mathrm{MHz}\right): \delta 156.06\left(\mathrm{C}_{2}\right.$ py $), 150.57$ ( $\mathrm{C}_{6}$ py), $143.60\left(\mathrm{C}_{4}\right.$ py $), 131.95\left(\mathrm{C}_{3}\right.$ py), $125.00\left(\mathrm{C}_{5}\right.$ py). Elem anal. Calcd for $1\left(\mathrm{C}_{15} \mathrm{H}_{12} \mathrm{~N}_{3} \mathrm{Sb}\right)$ : C, 50.6; H, 3.4; N, 11.8. Found: C. 50.3; H. 3.5; N. 12.1. HR-MS (MALDI, positive-ion mode MALDI-TOF). Calcd for $\mathrm{C}_{15} \mathrm{H}_{13} \mathrm{~N}_{3} \mathrm{Sb}\left([1+\mathrm{H}]^{+}\right): m / z$ 356.0142. Found: $\mathrm{m} / z$ 356.0141 ( $-0.1 \mathrm{ppm}$ error).

Synthesis of 2. 3-Bromopyridine $(1.92 \mathrm{~mL}, 20 \mathrm{mmol})$ was added dropwise over $30 \mathrm{~min}$ to a stirred solution of a $1.3 \mathrm{M}$ isopropylmagnesium chloride/lithium chloride complex in THF (15.4 mL, $20 \mathrm{mmol}, 1.3 \mathrm{M}$ in THF) at $-0{ }^{\circ} \mathrm{C}$. The resulting orange 
solution was stirred for $1 \mathrm{~h}$ at $0{ }^{\circ} \mathrm{C}$. A solution of $\mathrm{BiBr}_{3}(2.99 \mathrm{~g}, 6.66$ $\mathrm{mmol})$ in THF $(10 \mathrm{~mL})$ was added dropwise to the orange solution. The resulting mixture was allowed to reach room temperature. After overnight stirring, a colorless solution with a white precipitate was observed. All volatiles were removed under vacuum. DCM $(200 \mathrm{~mL})$ was added to the precipitate, and the resulting white suspension was treated with $\mathrm{H}_{2} \mathrm{O}(100 \mathrm{~mL} \times 3)$. The organic phase was dried over anhydrous magnesium sulfate. The suspension was filtered through Celite to yield a colorless solution, which was concentrated under vacuum, and slow diffusion of $n$-hexane $(20 \mathrm{~mL})$ at $-24{ }^{\circ} \mathrm{C}$ yielded 2 as white plates suitable for $\mathrm{X}$-ray crystallography. Yield: $2.38 \mathrm{~g}$ (5.36 mmol, 80\%). ${ }^{1} \mathrm{H}$ NMR $\left(298 \mathrm{~K}, \mathrm{CDCl}_{3}, 500 \mathrm{MHz}\right): \delta 8.76(\mathrm{~s}, 3 \mathrm{H}$, $\mathrm{H}_{2}$ py), 8.64 (d, $J=5.0 \mathrm{~Hz}, 3 \mathrm{H}, \mathrm{H}_{6}$ py), $8.02\left(\mathrm{~d}, J=7.6 \mathrm{~Hz}, 3 \mathrm{H}, \mathrm{H}_{4} \mathrm{py}\right)$, $7.34\left(\mathrm{~m}, 3 \mathrm{H}, \mathrm{H}_{5}\right.$ py). ${ }^{13} \mathrm{C}\left\{{ }^{1} \mathrm{H}\right\} \mathrm{NMR}\left(298 \mathrm{~K}, \mathrm{CDCl}_{3}, 100.6 \mathrm{MHz}\right): \delta$ $157.05\left(\mathrm{C}_{2}\right.$ py), $149.55\left(\mathrm{C}_{6} \mathrm{py}\right), 147.82$ (br, $\left.\mathrm{C}_{3} \mathrm{py}\right), 144.91\left(\mathrm{C}_{4} \mathrm{py}\right)$, $126.57\left(\mathrm{C}_{5}\right.$ py). Elem anal. Calcd for $2\left(\mathrm{C}_{15} \mathrm{H}_{12} \mathrm{~N}_{3} \mathrm{Bi}\right): \mathrm{C}, 40.6 ; \mathrm{H}, 2.7$; $\mathrm{N}, 9.5$. Found: $\mathrm{C}, 40.4 ; \mathrm{H}, 2.8 ; \mathrm{N}, 9.5$. HR-MS [ESI, positive-ion mode ESI-TOF]. Calcd for $\mathrm{C}_{15} \mathrm{H}_{13} \mathrm{~N}_{3} \mathrm{Bi}\left([2+\mathrm{H}]^{+}\right): \mathrm{m} / z 444.0908$. Found: $m / z 444.0922$ ( $-1.4 \mathrm{ppm}$ error).

Synthesis of $1 \cdot \mathrm{CuBF}_{4}$. A solution of $\mathbf{1}(35 \mathrm{mg}, 0.098 \mathrm{mmol})$ in dry DCM $(5 \mathrm{~mL})$ was prepared in a narrow Schlenk flask under a $\mathrm{N}_{2}$ atmosphere. A layer of $\mathrm{MeCN}(5 \mathrm{~mL}$ ) was layered on top of the ligand solution, and a solution of $\left[\mathrm{Cu}(\mathrm{MeCN})_{4}\right] \mathrm{BF}_{4}(30.9 \mathrm{mg}, 0.098$ $\mathrm{mmol})$ in dry $\mathrm{MeCN}(5 \mathrm{~mL})$ was then layered carefully on top of the $\mathrm{MeCN}$ layer. The three layers were left to diffuse slowly at room temperature over 1 week, resulting in yellow crystals of $\mathbf{1} \cdot \mathrm{CuBF}_{4}$ suitable for X-ray crystallography. Yield: $33 \mathrm{mg}(0.071 \mathrm{mmol}, 72 \%)$. Characterization of the product by NMR spectroscopy and mass spectrometry was impeded by its insolubility in suitable solvents. Elem anal. Calcd for $\mathbf{1} \cdot \mathrm{CuBF}_{4}\left(\mathrm{C}_{15} \mathrm{H}_{12} \mathrm{NCuF}_{4} \mathrm{~N}_{3} \mathrm{Sb}\right)$ : C, 35.6; H, 2.4; $\mathrm{N}, 8.3$. Found: $\mathrm{C}, 35.5 ; \mathrm{H}, 2.5 ; \mathrm{N}, 8.5$. In addition, the precipitate and crystals were confirmed to be identical by PXRD (see the SI).

Synthesis of $1 . \mathrm{CuPF}_{6}$. A solution of $1(25 \mathrm{mg}, 0.070 \mathrm{mmol})$ in dry DCM $(5 \mathrm{~mL})$ was prepared in a narrow Schlenk flask under a $\mathrm{N}_{2}$ atmosphere. A layer of $\mathrm{MeCN}(5 \mathrm{~mL})$ was layered on top of the ligand solution, and a solution of $\left[\mathrm{Cu}(\mathrm{MeCN})_{4}\right] \mathrm{PF}_{6}(26.2 \mathrm{mg}, 0.070$ $\mathrm{mmol})$ in dry MeCN $(5 \mathrm{~mL})$ was then layered carefully on top of the $\mathrm{MeCN}$ layer. The three layers were left to diffuse slowly at room temperature for a week, resulting in yellow crystals of $1 \bullet \mathrm{CuPF}_{6}$ suitable for X-ray crystallography. Yield: $31.2 \mathrm{mg}$ (0.055 mmol, 79\%). Characterization of the product by NMR spectroscopy and MS was impeded by its insolubility in suitable solvents. Elem anal. Calcd for $\mathbf{1}$. $\mathrm{CuPF}_{6}\left(\mathrm{C}_{15} \mathrm{H}_{12} \mathrm{CuF}_{6} \mathrm{~N}_{3} \mathrm{PSb}\right): \mathrm{C}, 31.9 ; \mathrm{H}, 2.1 ; \mathrm{N}, 7.4$. Found: $\mathrm{C}, 32.1$; $\mathrm{H}, 2.4 ; \mathrm{N}, 7.7$. In addition, the precipitate and the crystals were confirmed to be identical by powder diffraction (see the SI).

Synthesis of $1 \cdot \mathrm{AgBF}_{4}$. A solution of $1(40 \mathrm{mg}, 0.11 \mathrm{mmol})$ in dry DCM $(5 \mathrm{~mL})$ was prepared in a narrow Schlenk flask under a $\mathrm{N}_{2}$ atmosphere in the dark. A layer of $\mathrm{MeCN}(5 \mathrm{~mL})$ was layered on top of the ligand solution, and a solution of $\mathrm{AgBF}_{4}(21.9 \mathrm{mg}, 0.11 \mathrm{mmol})$ in dry $\mathrm{MeCN}(5 \mathrm{~mL})$ was then layered carefully on top of the $\mathrm{MeCN}$ layer. The three layers were left to diffuse slowly at room temperature for 1 week, resulting in colorless crystals of $\mathbf{1} \cdot \mathrm{AgBF}_{4}$ suitable for X-ray crystallography. Yield: $35 \mathrm{mg}(0.064 \mathrm{mmol}, 58 \%)$. Characterization of the product by NMR spectroscopy was impeded by its insolubility in suitable solvents. Elem anal. Calcd for $1 \cdot \mathrm{AgBF}_{4}\left(\mathrm{C}_{15} \mathrm{H}_{12} \mathrm{AgBF}_{4} \mathrm{~N}_{3} \mathrm{Sb}\right)$ : C, 32.7; H, 2.2; N, 7.6. Found: C, 32.7; H, 2.3; N, 7.7. HR-MS [ESI, positive-ion mode ESI-TOF $]$. Calcd for $\mathrm{C}_{15} \mathrm{H}_{12} \mathrm{AgN}_{3} \mathrm{Sb}\left([1+\mathrm{Ag}]^{+}\right)$: $\mathrm{m} / z$ 463.9115. Found: $\mathrm{m} / z 463.9125$ ( $-1.0 \mathrm{ppm}$ error). In addition, the precipitate and crystals were confirmed to be identical by PXRD (see the SI).

Synthesis of 1.AgPF 6 . A solution of $\mathbf{1}(25 \mathrm{mg}, 0.070 \mathrm{mmol})$ in dry DCM $(5 \mathrm{~mL})$ was prepared in a narrow Schlenk flask under a $\mathrm{N}_{2}$ atmosphere in the dark. A layer of $\mathrm{MeCN}(5 \mathrm{~mL})$ was layered on top of the ligand solution, and a solution of $\mathrm{AgPF}_{6}(17.7 \mathrm{mg}, 0.070 \mathrm{mmol})$ in dry $\mathrm{MeCN}(5 \mathrm{~mL})$ was then layered carefully on top of the $\mathrm{MeCN}$ layer. The three layers were left to diffuse slowly at room temperature for 1 week, resulting in colorless crystals of $\mathbf{1} \cdot \mathrm{AgPF}_{6}$ suitable for X-ray crystallography. Yield: $22.3 \mathrm{mg}(0.036 \mathrm{mmol}, 52 \%)$. Characterization of the product by NMR spectroscopy and MS was impeded by its insolubility in suitable solvents. Elem anal. Calcd for $1 \cdot \mathrm{AgPF}_{6}$
$\left(\mathrm{C}_{15} \mathrm{H}_{12} \mathrm{AgF}_{6} \mathrm{~N}_{3} \mathrm{PSb}\right): \mathrm{C}, 29.6 ; \mathrm{H}, 2.0 ; \mathrm{N}, 6.9$. Found: C, 29.5; H, $1.2 ; \mathrm{N}, 7.0$. In addition, the precipitate and crystals were confirmed to be identical by PXRD (see the SI).

Synthesis of $1 \cdot \mathrm{AgSbF}_{6}$. A solution of $1(40 \mathrm{mg}, 0.11 \mathrm{mmol})$ in dry DCM $(5 \mathrm{~mL})$ was prepared in a narrow Schlenk flask under a $\mathrm{N}_{2}$ atmosphere in the dark. A layer of $\mathrm{MeCN}(5 \mathrm{~mL})$ was layered on top of the ligand solution, and then a solution of $\mathrm{AgSbF}_{6}(38.5 \mathrm{mg}, 0.11$ $\mathrm{mmol}$ ) in dry $\mathrm{MeCN}(5 \mathrm{~mL})$ was layered carefully on top of the $\mathrm{MeCN}$ layer. The three layers were left to diffuse slowly at room temperature over 1 week, resulting in colorless crystals of $1 \cdot \mathrm{AgSbF}_{6}$ suitable for X-ray crystallography. Yield: $38.6 \mathrm{mg}$ (0.057 mmol, 51\%). Characterization of the product by NMR spectroscopy and MS was impeded by its insolubility in suitable solvents. Elem anal. Calcd for $\mathbf{1}$. $\mathrm{AgSbF}_{6}\left(\mathrm{C}_{15} \mathrm{H}_{12} \mathrm{AgF}_{6} \mathrm{~N}_{3} \mathrm{Sb}_{2}\right): \mathrm{C}, 25.8 ; \mathrm{H}, 1.7 ; \mathrm{N}, 6.0$. Found: C, 26.0; $\mathrm{H}, 1.9 ; \mathrm{N}, 6.5$. In addition, the precipitate and crystals were confirmed to be identical by PXRD (see the SI).

Synthesis of 1.AgOTf. A solution of $1(25 \mathrm{mg}, 0.070 \mathrm{mmol})$ in dry DCM $(5 \mathrm{~mL})$ was prepared in a narrow Schlenk flask under a $\mathrm{N}_{2}$ atmosphere in the dark. A layer of $\mathrm{MeCN}(5 \mathrm{~mL})$ was layered on top of the ligand solution, and then a solution of AgOTf $(18 \mathrm{mg}, 0.070$ $\mathrm{mmol}$ ) in dry $\mathrm{MeCN}(5 \mathrm{~mL})$ was layered carefully on top of the $\mathrm{MeCN}$ layer. The three layers were left to diffuse slowly at room temperature over 1 week, resulting in colorless crystals of $1 \cdot A g O T f$ suitable for X-ray crystallography. Yield: $25 \mathrm{mg}$ (0.041 mmol, 59\%). Characterization of the product by NMR spectroscopy and MS was impeded by its insolubility in suitable solvents. Elem anal. Calcd for $\mathbf{1}$. $\operatorname{AgOTf}\left(\mathrm{C}_{16} \mathrm{H}_{12} \mathrm{AgF}_{3} \mathrm{~N}_{3} \mathrm{O}_{3} \mathrm{SSb}\right)$ : C, 31.4; H, 2.0; N, 6.9; S, 5.2. Found: $\mathrm{C}, 31.6 ; \mathrm{H}, 2.0 ; \mathrm{N}, 7.5 ; \mathrm{S}, 5.3$. In addition, the precipitate and crystals were confirmed to be identical by PXRD (see the SI).

Synthesis of $2 \cdot \mathrm{CuPF}_{6}$. A solution of $2(50 \mathrm{mg}, 0.11 \mathrm{mmol})$ in dry DCM $(5 \mathrm{~mL})$ was prepared in a narrow Schlenk flask under a $\mathrm{N}_{2}$ atmosphere. A layer of $\mathrm{MeCN}(5 \mathrm{~mL})$ was layered on top of the ligand solution, and a solution of $\left[\mathrm{Cu}(\mathrm{MeCN})_{4}\right] \mathrm{PF}_{6}(42 \mathrm{mg}, 0.11$ $\mathrm{mmol}$ ) in dry $\mathrm{MeCN}(5 \mathrm{~mL})$ was then layered carefully on top of the $\mathrm{MeCN}$ layer. The three layers were left to diffuse slowly at room temperature for 1 month, resulting in yellow crystals of $2 \cdot \mathrm{CuPF}_{6}$ suitable for X-ray crystallography. Yield: $34.3 \mathrm{mg}$ (0.052 mmol, $48 \%)$. Characterization of the product by NMR spectroscopy and MS was impeded by its insolubility in suitable solvents. Elem anal. Calcd for $\mathbf{2}$. $\mathrm{CuPF}_{6}\left(\mathrm{C}_{15} \mathrm{H}_{12} \mathrm{BiCuF}_{6} \mathrm{~N}_{3} \mathrm{P}\right)$ : C, 27.6; H, 1.9; N, 6.4. Found: C, 27.9; $\mathrm{H}, 2.1 ; \mathrm{N}, 6.3$. In addition, the precipitate and crystals were confirmed to be identical by PXRD (see the SI).

Synthesis of 2.AgSbF 6 . A solution of $2(40 \mathrm{mg}, 0.090 \mathrm{mmol})$ in dry DCM $(5 \mathrm{~mL})$ was prepared in a narrow Schlenk flask under a $\mathrm{N}_{2}$ atmosphere in the dark. A layer of $\mathrm{MeCN}(5 \mathrm{~mL})$ was layered on top of the ligand solution, and a solution of $\mathrm{AgSbF}_{6}(31.3 \mathrm{mg}, 0.090$ $\mathrm{mmol})$ in dry $\mathrm{MeCN}(5 \mathrm{~mL})$ was then layered carefully on top of the $\mathrm{MeCN}$ layer. The three layers were left to diffuse slowly at room temperature for 1 month, resulting in colorless crystals of $2 \cdot \mathrm{AgSbF}_{6}$ suitable for X-ray crystallography. Yield: $22.5 \mathrm{mg}$ (0.028 mmol, 32\%). Characterization of the product by NMR spectroscopy and MS was impeded by its insolubility in suitable solvents. Elem anal. Calcd for $\mathbf{2}$. $\mathrm{AgSbF}_{6}\left(\mathrm{C}_{15} \mathrm{H}_{12} \mathrm{AgBiF}_{6} \mathrm{~N}_{3} \mathrm{Sb}\right): \mathrm{C}, 22.9 ; \mathrm{H}, 1.5 ; \mathrm{N}, 5.3$. Found: C, $21.3 ; \mathrm{H}, 0.5 ; \mathrm{N}, 5.1$. The crystals of $2 \cdot \mathrm{AgSbF}_{6}$ were isolated in the presence of a black amorphous solid, which hampered elemental analysis. In addition, the precipitate and crystals were confirmed to be identical by PXRD (see the SI).

Synthesis of 2.CuBF 4 . A solution of $2(30 \mathrm{mg}, 0.067 \mathrm{mmol})$ in dry DCM $(5 \mathrm{~mL})$ was prepared in a narrow Schlenk flask under a $\mathrm{N}_{2}$ atmosphere. A solution of $\left[\mathrm{Cu}(\mathrm{MeCN})_{4}\right] \mathrm{BF}_{4}(10.5 \mathrm{mg}, 0.037 \mathrm{mmol})$ in dry $\mathrm{MeCN}(5 \mathrm{~mL})$ was layered carefully on top of the ligand solution. The two layers were left to diffuse slowly at room temperature for 1 month, resulting in yellow crystals of $2 \cdot \mathrm{CuBF}_{4}$ suitable for X-ray crystallography. Yield: $14.3 \mathrm{mg}(0.013 \mathrm{mmol}$, $37.3 \%$ ). Characterization of the product by NMR spectroscopy and MS was impeded by its insolubility in suitable solvents. Elem anal. Calcd for $2 \cdot \mathrm{CuBF}_{4}\left(\mathrm{C}_{30} \mathrm{H}_{24} \mathrm{BBi}_{2} \mathrm{CuF}_{4} \mathrm{~N}_{6}\right)$ : C, 34.7; H, 2.3; N, 8.1. Found: $\mathrm{C}, 34.2 ; \mathrm{H}, 2.4 ; \mathrm{N}, 8.2$. In addition, the precipitate and crystals were confirmed to be identical by PXRD (see the SI). 
Synthesis of 2.LiBr.MeCN. A solution of $2(50 \mathrm{mg}, 0.11 \mathrm{mmol})$ in dry DCM $(5 \mathrm{~mL})$ was prepared in a narrow Schlenk flask under a $\mathrm{N}_{2}$ atmosphere. A solution of $\mathrm{LiBr}(9.8 \mathrm{mg}, 0.11 \mathrm{mmol})$ in dry $\mathrm{MeCN}(5$ $\mathrm{mL}$ ) was layered carefully on top of the ligand solution. The two layers were left to diffuse slowly at room temperature over 1 month, resulting in yellow crystals of $2 \cdot \mathrm{LiBr} \cdot \mathrm{MeCN}$ suitable for X-ray crystallography. Yield: $30.2 \mathrm{mg}(0.052 \mathrm{mmol}, 48 \%)$. Characterization of the product by NMR spectroscopy and MS was impeded by its insolubility in suitable solvents. Elem anal. Calcd for $2 \cdot \mathrm{LiBr} \cdot \mathrm{MeCN}$ $\left(\mathrm{C}_{17} \mathrm{H}_{15} \mathrm{BiBrLiN}_{4}\right): \mathrm{C}, 35.7 ; \mathrm{H}, 2.6 ; \mathrm{N}, 9.8$. Found: $\mathrm{C}, 35.0 ; \mathrm{H}, 2.7 ; \mathrm{N}$, 9.7. In addition, the precipitate and crystals were confirmed to be identical by PXRD (see the SI).

\section{ASSOCIATED CONTENT}

\section{(s) Supporting Information}

The Supporting Information is available free of charge at https://pubs.acs.org/doi/10.1021/acs.inorgchem.1c03004.

NMR spectra, additional X-ray structures, details and information, and HR-MS data (PDF)

\section{Accession Codes}

CCDC 2110782-2110793 contain the supplementary crystallographic data for this paper. These data can be obtained free of charge via www.ccdc.cam.ac.uk/data_request/cif, or by emailing data_request@ccdc.cam.ac.uk, or by contacting The Cambridge Crystallographic Data Centre, 12 Union Road, Cambridge CB2 1EZ, UK; fax: +44 1223336033.

\section{AUTHOR INFORMATION}

\section{Corresponding Authors}

Celedonio M. Álvarez - GIR MIOMeT-IU, Cinquima, Quimica Inorgánica, Facultad de Ciencias, Universidad de Valladolid, 47011 Valladolid, Spain; ๑ orcid.org/00000003-4431-6501; Email: celedonio.alvarez@uva.es

Raúl García-Rodríguez - GIR MIOMeT-IU, Cinquima, Química Inorgánica, Facultad de Ciencias, Universidad de Valladolid, 47011 Valladolid, Spain; $\odot$ orcid.org/00000003-0699-3894; Email: raul.garcia.rodriguez@uva.es

\section{Authors}

Álvaro García-Romero - GIR MIOMeT-IU, Cinquima, Quimica Inorgánica, Facultad de Ciencias, Universidad de Valladolid, 47011 Valladolid, Spain

Jose M. Martín-Álvarez - GIR MIOMeT-IU, Cinquima, Química Inorgánica, Facultad de Ciencias, Universidad de Valladolid, 47011 Valladolid, Spain; $\odot$ orcid.org/00000002-6969-0703

Daniel Miguel - GIR MIOMeT-IU, Cinquima, Química Inorgánica, Facultad de Ciencias, Universidad de Valladolid, 47011 Valladolid, Spain; ๑ orcid.org/0000-0003-06503058

Dominic S. Wright - Department of Chemistry, University of Cambridge, Cambridge CB2 1EW, U.K.; ๑ orcid.org/00000002-9952-3877

Complete contact information is available at: https://pubs.acs.org/10.1021/acs.inorgchem.1c03004

\section{Author Contributions}

The manuscript was written through contributions of all authors.

\section{Notes}

The authors declare no competing financial interest.

\section{ACKNOWLEDGMENTS}

We thank the Spanish Ministry of Science, Innovation and Universities [MCIU; Projects PGC2018-096880-A-I00 and PGC2018-099470-B-I00 (MCIU/AEI/FEDER, UE)] and the Leverhulme Trust (RPG-2017-146 to D.S.W.) for funding. R.G.-R. acknowledges the Spanish MINECO/AEI and the European Union (ESF) for a Ramon y Cajal contract (RYC2015-19035), and A.G.-R. acknowledges the University of Valladolid and Santander Bank for a fellowship. We also thank Gregori Ujaque for assistance with DFT calculations.

\section{REFERENCES}

(1) Moberg, C. $\mathrm{C}_{3}$ Symmetry in Asymmetric Catalysis and Chiral Recognition. Angew. Chem., Int. Ed. 1998, 37 (3), 248-268.

(2) Dro, C.; Bellemin-Laponnaz, S.; Welter, R.; Gade, L. H. A C $3^{-}$ Symmetrical Chiral Trisoxazoline Zinc Complex as a Functional Model for Zinc Hydrolases: Kinetic Resolution of Racemic Chiral Esters by Transesterification. Angew. Chem., Int. Ed. 2004, 43 (34), 4479-4482

(3) Camasso, N. M.; Sanford, M. S. Design, Synthesis, and CarbonHeteroatom Coupling Reactions of Organometallic Nickel(IV) Complexes. Science 2015, 347 (6227), 1218-1220.

(4) Vogel, C.; Heinemann, F. W.; Sutter, J.; Anthon, C.; Meyer, K. An Iron Nitride Complex. Angew. Chem., Int. Ed. 2008, 47 (14), $2681-2684$.

(5) Solyntjes, S.; Neumann, B.; Stammler, H. G.; Ignat'ev, N.; Hoge, B. Bismuth Perfluoroalkylphosphinates: New Catalysts for Application in Organic Syntheses. Chem. - Eur. J. 2017, 23 (7), 1568-1575.

(6) Kaufhold, S.; Rosemann, N. W.; Chábera, P.; Lindh, L.; Bolaño Losada, I.; Uhlig, J.; Pascher, T.; Strand, D.; Wärnmark, K.; Yartsev, A.; Persson, P. Microsecond Photoluminescence and Photoreactivity of a Metal-Centered Excited State in a Hexacarbene-Co(III) Complex. J. Am. Chem. Soc. 2021, 143 (3), 1307-1312.

(7) Hofman, P.; Gade, L. H. Molecular Catalysis: Structure and Functional Design; Wiley-VCH: Weinheim, Germany, 2014.

(8) Trofimenko, S. Recent Advances in Poly(Pyrazolyl)Borate (Scorpionate) Chemistry. Chem. Rev. 1993, 93 (3), 943-980.

(9) Szczepura, L. F.; Witham, L. M.; Takeuchi, K. J. Tris(2-Pyridyl) Tripod Ligands. Coord. Chem. Rev. 1998, 174 (1), 5-32.

(10) Simmonds, H. R.; Wright, D. S. Main Group Pyridyl-Based Ligands; Strategies to Mixed Metal Complexes. Chem. Commun. 2012, 48 (69), 8617-8624.

(11) Peel, A. J.; Waters, J. E.; Plajer, A. J.; García-Rodríguez, R.; Wright, D. S. Recent Advances in the Synthesis and Application of Tris(Pyridyl) Ligands Containing Metallic and Semimetallic p-Block Bridgeheads. Advances in Organometallic Chemistry; Academic Press Inc., 2021; Vol. 75, pp 193-244.

(12) Zeckert, K.; Griebel, J.; Kirmse, R.; Weiß, M.; Denecke, R. Versatile Reactivity of a Lithium Tris(Aryl)Plumbate(II) towards Organolanthanoid Compounds: Stable Lead-Lanthanoid-Metal Bonds or Redox Processes. Chem. - Eur. J. 2013, 19 (24), 7718-7722.

(13) Schrader, I.; Zeckert, K.; Zahn, S. Dilithium Hexaorganostannate(IV) Compounds. Angew. Chem., Int. Ed. 2014, 53 (50), 13698-13700.

(14) García-Romero, Á.; Plajer, A. J.; Miguel, D.; Wright, D. S.; Bond, A. D.; Álvarez, C. M.; García-Rodríguez, R. Tris(2-Pyridyl) Bismuthines: Coordination Chemistry, Reactivity, and AnionTriggered Pyridyl Coupling. Inorg. Chem. 2020, 59 (10), 7103-7116. (15) García-Rodríguez, R.; Hanf, S.; Bond, A. D.; Wright, D. S. A Non-Chiral Lithium Aluminate Reagent for the Determination of Enantiomeric Excess of Chiral Alcohols. Chem. Commun. 2017, 53 (7), 1225-1228.

(16) García-Romero, Á.; Plajer, A. J.; Álvarez-Miguel, L.; Bond, A. D.; Wright, D. S.; García-Rodríguez, R. Postfunctionalization of Tris(Pyridyl) Aluminate Ligands: Chirality, Coordination, and Supramolecular Chemistry. Chem. - Eur. J. 2018, 24 (64), 1701917026 
(17) Zeckert, K.; Fuhrmann, D. Bis(2-Pyridyl) and Tris(2-Pyridyl) Compounds of Gallium and Indium via a Redox-Transmetalation Route. Inorg. Chem. 2019, 58 (24), 16736-16742.

(18) Jeong, S. Y.; Lalancette, R. A.; Lin, H.; Lupinska, P.; Shipman, P. O.; John, A.; Sheridan, J. B.; Jäkle, F. Third-Generation"-Type Functional Tris(2-Pyridyl)Borate Ligands and Their Transition-Metal Complexes. Inorg. Chem. 2016, 55 (7), 3605-3615.

(19) Cui, C.; Lalancette, R. A.; Jäkle, F. The Elusive Tripodal Tris(2Pyridyl)Borate Ligand: A Strongly Coordinating Tetraarylborate. Chem. Commun. 2012, 48 (55), 6930-6932.

(20) Morales, D.; Pérez, J.; Riera, L.; Riera, V.; Miguel, D. Molybdenum and Tungsten Tricarbonyl Complexes with the Tripodal Ligands [ $\left.{ }^{\mathrm{n}} \mathrm{BuSn}(2 \text {-Pyridyl })_{3}\right]$ and [RSn(Methylthiomethyl) $)_{3}$. Organometallics 2001, 20 (22), 4517-4523.

(21) Plajer, A. J.; Crusius, D.; Jethwa, R. B.; García-Romero, A.; Bond, A. D.; García-Rodríguez, R.; Wright, D. S. Coordination Chemistry of the Bench-Stable Tris-2-Pyridyl Pnictogen Ligands [E(6-Me-2-Py $\left.)_{3}\right](\mathrm{E}=\mathrm{As}, \mathrm{AsO}, \mathrm{Sb})$. Dalt. Trans. 2021, 50 (7), 23932402.

(22) Plajer, A. J.; Colebatch, A. L.; Rizzuto, F. J.; Pröhm, P.; Bond, A. D.; García-Rodríguez, R.; Wright, D. S. How Changing the Bridgehead Can Affect the Properties of Tripodal Ligands. Angew. Chem., Int. Ed. 2018, 57 (22), 6648-6652.

(23) Kimura, S.; Uejima, M.; Ota, W.; Sato, T.; Kusaka, S.; Matsuda, R.; Nishihara, H.; Kusamoto, T. An Open-Shell, Luminescent, TwoDimensional Coordination Polymer with a Honeycomb Lattice and Triangular Organic Radical. J. Am. Chem. Soc. 2021, 143 (11), 43294338.

(24) Kleij, A. W.; Lutz, M.; Spek, A. L.; Van Leeuwen, P. W. N. M.; Reek, J. N. H. Encapsulated Transition Metal Catalysts Comprising Peripheral Zn(II)Salen Building Blocks: Template-Controlled Reactivity and Selectivity in Hydroformylation Catalysis. Chem. Commun. 2005, 29, 3661-3663.

(25) Waters, J. E.; Berger, G.; Peel, A. J.; García-Rodríguez, R.; Bond, A. D.; Wright, D. S. Uncovering the Hidden Landscape of Tris(4-Pyridyl) Ligands: Topological Complexity Derived from the Bridgehead. Chem. - Eur. J. 2021, 27 (47), 12036-12040.

(26) Bocokić, V.; Kalkan, A.; Lutz, M.; Spek, A. L.; Gryko, D. T.; Reek, J. N. H. Capsule-Controlled Selectivity of a Rhodium Hydroformylation Catalyst. Nat. Commun. 2013, 4 (1), 1-9.

(27) Kluwer, A. M.; Kapre, R.; Hartl, F.; Lutz, M.; Spek, A. L.; Brouwer, A. M.; Van Leeuwen, P. W. N. M.; Reek, J. N. H. SelfAssembled Biomimetic [2Fe2S]-Hydrogenase-Based Photocatalyst for Molecular Hydrogen Evolution. Proc. Natl. Acad. Sci. U. S. A. 2009, 106 (26), 10460-10465.

(28) Jacobs, I.; Van Duin, A. C. T.; Kleij, A. W.; Kuil, M.; Tooke, D. M.; Spek, A. L.; Reek, J. N. H. Conformational Studies of LigandTemplate Assemblies and the Consequences for Encapsulation of Rhodium Complexes and Hydroformylation Catalysis. Catal. Sci. Technol. 2013, 3 (8), 1955-1963.

(29) Wang, X.; Nurttila, S. S.; Dzik, W. I.; Becker, R.; Rodgers, J.; Reek, J. N. H. Tuning the Porphyrin Building Block in Self-Assembled Cages for Branched-Selective Hydroformylation of Propene. Chem. Eur. J. 2017, 23 (59), 14769-14777.

(30) García-Romero, Á.; Martín-Álvarez, J. M.; Colebatch, A. L.; Plajer, A. J.; Miguel, D.; Álvarez, C. M.; García-Rodríguez, R. Synthesis of Tris(3-Pyridyl)Aluminate Ligand and Its Unexpected Stability against Hydrolysis: Revealing Cooperativity Effects in Heterobimetallic Pyridyl Aluminates. Dalton. Trans. 2021, 50, 13059. (31) Deshmukh, M. S.; Yadav, A.; Pant, R.; Boomishankar, R. Thermochromic and Mechanochromic Luminescence Umpolung in Isostructural Metal-Organic Frameworks Based on $\mathrm{Cu}_{6} \mathrm{I}_{6}$ Clusters. Inorg. Chem. 2015, 54 (4), 1337-1345.

(32) Kumar, K. S.; Mane, V. S.; Yadav, A.; Kumbhar, A. S.; Boomishankar, R. Photochemical Hydrogen Evolution from Water by a 1D-Network of Octahedral $\mathrm{Ni}_{6} \mathrm{~L}_{8}$ Cages. Chem. Commun. 2019, 55 (87), 13156-13159.

(33) Deshmukh, M. S.; Mane, V. S.; Kumbhar, A. S.; Boomishankar, R. Light-Driven Hydrogen Evolution from Water by a Tripodal Silane
Based $\mathrm{Co}_{6}{ }_{6} \mathrm{~L}_{8}^{1}$ Octahedral Cage. Inorg. Chem. 2017, 56 (21), 1328613292.

(34) Yang, E. S.; Plajer, A. J.; García-Romero, Á.; Bond, A. D.; Ronson, T. K.; Álvarez, C. M.; García-Rodríguez, R.; Colebatch, A. L.; Wright, D. S. A Tris(3-Pyridyl)Stannane as a Building Block for Heterobimetallic Coordination Polymers and Supramolecular Cages. Chem. - Eur. J. 2019, 25 (61), 14003-14009.

(35) Custelcean, R. Anions in Crystal Engineering. Chem. Soc. Rev. 2010, 39 (10), 3675-3685.

(36) Clegg, J. K.; Lindoy, L. F. In Anion Coordination Chemistry; Bowman-James, K., Bianchi, A., Garcia-España, E., Eds.; Wiley-VCH: Weinheim, Germany, 2011; p 289.

(37) Krasovskiy, A.; Knochel, P. A LiCl-Mediated Br/Mg Exchange Reaction for the Preparation of Functionalized Aryl- and Heteroarylmagnesium Compounds from Organic Bromides. Angew. Chem., Int. Ed. 2004, 43 (25), 3333-3336.

(38) Urgin, K.; Aubé, C.; Pichon, C.; Pipelier, M.; Blot, V.; ThobieGautier, C.; Léonel, E.; Dubreuil, D.; Condon, S. Advanced Preparation of Functionalized Triarylbismuths and TriheteroarylBismuths: New Scope and Alternatives. Tetrahedron Lett. 2012, 53 (15), 1894-1896.

(39) Mantina, M.; Chamberlin, A. C.; Valero, R.; Cramer, C. J.; Truhlar, D. G. Consistent van der Waals Radii for the Whole Main Group. J. Phys. Chem. A 2009, 113 (19), 5806-5812.

(40) Bondi, A. Van Der Waals Volumes and Radii. J. Phys. Chem. 1964, 68 (3), 441-451.

(41) Cordero, B.; Gómez, V.; Platero-Prats, A. E.; Revés, M.; Echeverría, J.; Cremades, E.; Barragán, F.; Alvarez, S. Covalent Radii Revisited. J. Chem. Soc. Dalt. Trans. 2008, 21, 2832-2838.

(42) Pyykkö, P.; Atsumi, M. Molecular Single-Bond Covalent Radii for Elements 1-118. Chem. - Eur. J. 2009, 15 (1), 186-197.

(43) Bowmaker, G. A.; Effendy; Hart, R. D.; Kildea, J. D.; Skelton, B. W.; de Silva, E. N.; White, A. H. Lewis-Base Adducts of Group 11 Metal(I) Compounds. LXIV Syntheses, Spectroscopy and Structures of Some 1:4 Adducts of Copper(I) and Silver(I) Perchlorates with Triphenylarsine and Triphenylstibine. Aust. J. Chem. 1997, 50 (6), 539-552.

(44) Hill, A. M.; Levason, W.; Webster, M. Synthesis And ${ }^{109} \mathrm{Ag}$ NMR Studies of Homoleptic Silver(I) Stibines. Inorg. Chem. 1996, 35 (11), 3428-3430.

(45) Yamada, M.; Hagiwara, H.; Torigoe, H.; Matsumoto, N.; Kojima, M.; Dahan, F.; Tuchagues, J. P.; Re, N.; Iijima, S. A Variety of Spin-Crossover Behaviors Depending on the Counter Anion: TwoDimensional Complexes Constructed by $\mathrm{NH} \cdots \mathrm{Cl}^{-}$Hydrogen Bonds, $\left[\mathrm{Fe}^{\mathrm{II}} \mathrm{H}_{3} \mathrm{LMe}\right] \mathrm{Cl} \cdot \mathrm{X}\left(\mathrm{X}=\mathrm{PF}_{6}^{-}, \mathrm{AsF}_{6}^{-}, \mathrm{SbF}_{6}{ }^{-}, \mathrm{CF}_{3} \mathrm{SO}_{3}{ }^{-} ; \mathrm{H}_{3} \mathrm{~L}^{\mathrm{Me}}=\right.$ Tris $[2-\{[(2$ methylimidazol-4-yl $)$ methylidene $]$ amino $\}$ ethyl $]$ amine $)$. Chem. - Eur. J. 2006, 12 (17), 4536-4549.

(46) Lin, T. P.; Ke, I. S.; Gabbaï, F. P. $\sigma$-Accepting Properties of a Chlorobismuthine Ligand. Angew. Chem., Int. Ed. 2012, 51 (20), 4985-4988.

(47) Tschersich, C.; Limberg, C.; Roggan, S.; Herwig, C.; Ernsting, N.; Kovalenko, S.; Mebs, S. Gold- and Platinum-Bismuth DonorAcceptor Interactions Supported by an Ambiphilic PBiP Pincer Ligand. Angew. Chem., Int. Ed. 2012, 51 (20), 4989-4992.

(48) Tschersich, C.; Braun, B.; Herwig, C.; Limberg, C. Coordination of Noble Metals by an Ambiphilic PBiP Pincer Ligand: Metallophilic $\mathrm{Bi}-\mathrm{Cu}$ and $\mathrm{Bi}-\mathrm{Ag}$ Interactions. J. Organomet. Chem. 2015, 784, 62-68.

(49) Materne, K.; Hoof, S.; Frank, N.; Herwig, C.; Limberg, C. In Situ Formation of PBiP Ligands upon Complexation of a Mixed Phosphane/Bismuthane with Group 11 Metal Ions. Organometallics 2017, 36 (24), 4891-4895.

(50) Ke, I. S.; Gabbaï, F. P. $\mathrm{Cu}_{3}(\mu 2-\mathrm{Cl})_{3}$ and $\mathrm{Ag}_{3}\left(\mu_{2}-\mathrm{Cl}\right)_{3}$ Complexes Supported by Tetradentate Trisphosphino-Stibine and -Bismuthine Ligands: Structural Evidence for Triply Bridging Heavy Pnictines. Aust. J. Chem. 2013, 66 (10), 1281-1287.

(51) Gorelsky, S. I. AOMix: Program for Molecular Orbital Analysis, version 6.94; 2018; Http://Www.Sg-Chem.Net/. 
(52) CrysAlisPro-Data Collection and Integration Software; Agilent Technologies U.K. Ltd.: Oxford, U.K., 2011.

(53) Sheldrick, G. M. Crystal Structure Refinement with SHELXL. Acta Crystallogr., Sect. C: Struct. Chem. 2015, 71 (1), 3-8.

(54) Dolomanov, O. V.; Bourhis, L. J.; Gildea, R. J.; Howard, J. A. K.; Puschmann, H. OLEX2: A Complete Structure Solution, Refinement and Analysis Program. J. Appl. Crystallogr. 2009, 42 (2), 339-341.

(55) Macrae, C. F.; Sovago, I.; Cottrell, S. J.; Galek, P. T. A.; McCabe, P.; Pidcock, E.; Platings, M.; Shields, G. P.; Stevens, J. S.; Towler, M.; Wood, P. A. Mercury 4.0: from visualization to analysis, design and prediction. J. Appl. Crystallogr. 2020, 53, 226-235.

(56) Frisch, M. J.; Trucks, G. W.; Schlegel, H. B.; Scuseria, G. E.; Robb, M. A.; Cheeseman, J. R.; Scalmani, G.; Barone, V.; Petersson, G. A.; Nakatsuji, H.; Li, X.; Caricato, M.; Marenich, A. V.; Bloino, J.; Janesko, B. G.; Gomperts, R.; Mennucci, B.; Hratchian, H. P.; Ortiz, J. V.; Izmaylov, A. F.; Sonnenberg, J. L.; Williams-Young, D.; Ding, F.; Lipparini, F.; Egidi, F.; Goings, J.; Peng, B.; Petrone, A.; Henderson, T.; Ranasinghe, D.; Zakrzewski, V. G.; Gao, J.; Rega, N.; Zheng, G.; Liang, W.; Hada, M.; Ehara, M.; Toyota, K.; Fukuda, R.; Hasegawa, J.; Ishida, M.; Nakajima, T.; Honda, Y.; Kitao, O.; Nakai, H.; Vreven, T.; Throssell, K.; Montgomery, J. A., Jr.; Peralta, J. E.; Ogliaro, F.; Bearpark, M. J.; Heyd, J. J.; Brothers, E. N.; Kudin, K. N.; Staroverov, V. N.; Keith, T. A.; Kobayashi, R.; Normand, J.; Raghavachari, K.; Rendell, A. P.; Burant, J. C.; Iyengar, S. S.; Tomasi, J.; Cossi, M.; Millam, J. M.; Klene, M.; Adamo, C.; Cammi, R.; Ochterski, J. W.; Martin, R. L.; Morokuma, K.; Farkas, O.; Foresman, J. B.; Fox, D. J. Gaussian 16, revision C.01; Gaussian, Inc.: Wallingford, CT, 2019.

(57) Austin, A.; Petersson, G. A.; Frisch, M. J.; Dobek, F. J.; Scalmani, G.; Throssell, K. A Density Functional with Spherical Atom Dispersion Terms. J. Chem. Theory Comput. 2012, 8, 4989-5007.

(58) Peterson, K. A. Systematically Convergent Basis Sets with Relativistic Pseudopotentials. I. Correlation Consistent Basis Sets for the Post- d Group 13 - 15 Elements. J. Chem. Phys. 2003, 119 (21), 11099.

(59) Peterson, K. A.; Puzzarini, C. Systematically Convergent Basis Sets for Transition Metals. II. Pseudopotential-Based Correlation Consistent Basis Sets for the Group $11(\mathrm{Cu}, \mathrm{Ag}, \mathrm{Au})$ and $12(\mathrm{Zn}, \mathrm{Cd}$, Hg) Elements. Theor. Chem. Acc. 2005, 114, 283-296.

(60) Figgen, D.; Rauhut, G.; Dolg, M.; Stoll, H. Energy-Consistent Pseudopotentials for Group 11 and 12 Atoms: Adjustment to MultiConfiguration Dirac-Hartree-Fock Data. Chem. Phys. 2005, 311, 227-244.

(61) Metz, B.; Stoll, H.; Dolg, M. Small-core multiconfigurationDirac-Hartree-Fock-Adjusted Pseudopotentials for Post- d Main Group Elements: Application to $\mathrm{PbH}$ and PbO. J. Chem. Phys. 2000, 113 (7), 2563-2569.

(62) Pritchard, B. P.; Altarawy, D.; Didier, B.; Gibson, T. D.; Windus, T. L. New Basis Set Exchange: An Open, Up-to-Date Resource for the Molecular Sciences Community. J. Chem. Inf. Model. 2019, 59, 4814-4820.

(63) Glendening, E. D.; Badenhoop, J. K.; Reed, A. E.; Carpenter, J. E.; Bohmann, J. A.; Morales, C. M.; Karafiloglou, P.; Landis, C. R.; Weinhold, F. NBO 7.0; Theoretical Chemistry Institute, University of Wisconsin: Madison, WI, 2018.

(64) Gorelsky, S. I.; Lever, A. B. P. Electronic Structure and Spectra of Ruthenium Diimine Complexes by Density Functional Theory and INDO/S. Comparison of the Two Methods. J. Organomet. Chem. 2001, 635, 187-196.

(65) Dennington, R.; Keith, T. A.; Millam, J. M. GaussView, version 6.1; Semichem Inc.: Shawnee Mission, KS, 2016. 